\title{
Regular treatment with formoterol versus regular treatment with salmeterol for chronic asthma: serious adverse events (Review)
}

\author{
Cates CJ, Lasserson TJ
}

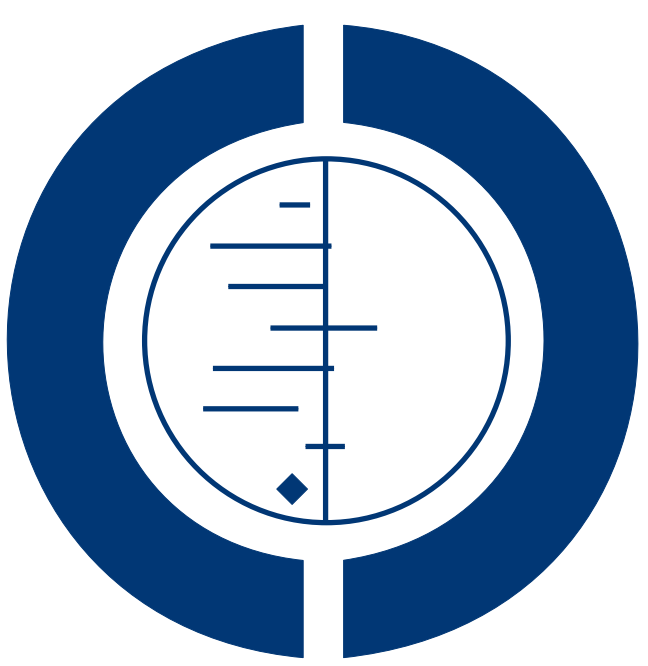

\section{THE COCHRANE COLLABORATION $^{\circledR}$}

This is a reprint of a Cochrane review, prepared and maintained by The Cochrane Collaboration and published in The Cochrane Library 2012, Issue 3

http://www.thecochranelibrary.com

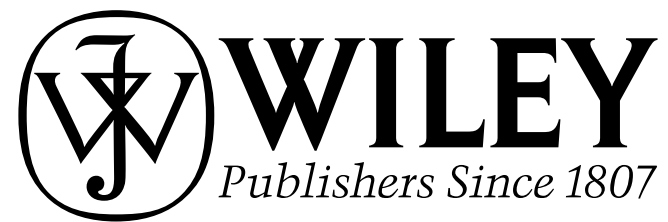

Regular treatment with formoterol versus regular treatment with salmeterol for chronic asthma: serious adverse events (Review)

Copyright (C) 2012 The Cochrane Collaboration. Published by John Wiley \& Sons, Ltd. 
TABLE OF CONTENTS

HEADER . . . . . . . . . . . . . . . . . . . . . . . . . . . . . . . . . . . . . . . 1

ABSTRACT . . . . . . . . . . . . . . . . . . . . . . . . . . . . . . . . . . . . . . . . . . . . . 1

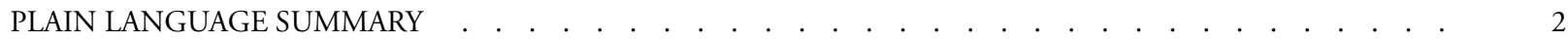

SUMMARY OF FINDINGS FOR THE MAIN COMPARISON . . . . . . . . . . . . . . . . . . . . 2

BACKGROUND . . . . . . . . . . . . . . . . . . . . . . . . . . . . . . . . . . . . 5

OBJECTIVES . . . . . . . . . . . . . . . . . . . . . . . . . . . . . . . . . . . . . 5

METHODS . . . . . . . . . . . . . . . . . . . . . . . . . . . . . . . . . . . . . . 5

RESULTS . . . . . . . . . . . . . . . . . . . . . . . . . . . . . . . . . . . . . . . 7

Figure 1. . . . . . . . . . . . . . . . . . . . . . . . . . . . . . . . . . . . . . 8

Figure 2. . . . . . . . . . . . . . . . . . . . . . . . . . . . . . . . . . . . . . . 9

Figure 3. . . . . . . . . . . . . . . . . . . . . . . . . . . . . . . . . . . . . . 10

Figure 4. . . . . . . . . . . . . . . . . . . . . . . . . . . . . . . . 11

DISCUSSION .. . . . . . . . . . . . . . . . . . . . . . . . . . . . . . . . . . . . 11

AUTHORS' CONCLUSIONS . . . . . . . . . . . . . . . . . . . . . . . . . . . . . . . . . . . 12

ACKNOWLEDGEMENTS . . . . . . . . . . . . . . . . . . . . . . . . . . . . . . . . . . . . . . . . . 12

REFERENCES . . . . . . . . . . . . . . . . . . . . . . . . . . . . . . . . . . . . . 12

CHARACTERISTICS OF STUDIES . . . . . . . . . . . . . . . . . . . . . . . . . . . . . . . . . 16

DATA AND ANALYSES . . . . . . . . . . . . . . . . . . . . . . . . . . . . . . . . . . . . . . . . . . $\quad 23$

Analysis 1.1. Comparison 1 Regular formoterol versus regular salmeterol, Outcome 1 All-cause mortality. . . . . . 24

Analysis 1.2. Comparison 1 Regular formoterol versus regular salmeterol, Outcome 2 All-cause SAEs. . . . . . . $\quad 25$

Analysis 1.3. Comparison 1 Regular formoterol versus regular salmeterol, Outcome 3 Asthma-related SAEs. . . . $\quad 26$

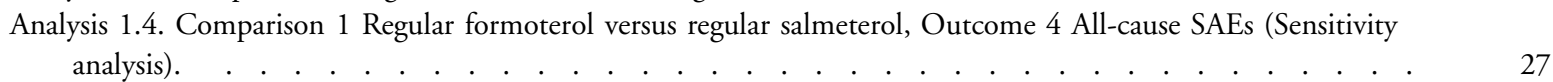

Analysis 1.5. Comparison 1 Regular formoterol versus regular salmeterol, Outcome 5 Asthma-related SAEs (Sensitivity analysis). . . . . . . . . . . . . . . . . . . . . . . . . . . . . . . . . . . . 28

ADDITIONAL TABLES . . . . . . . . . . . . . . . . . . . . . . . . . . . . . . . . . . 28

APPENDICES . . . . . . . . . . . . . . . . . . . . . . . . . . . . . . . . . . . . . 29

Figure 5. . . . . . . . . . . . . . . . . . . . . . . . . . . . . . . . . . . . . . 32

WHAT'S NEW . . . . . . . . . . . . . . . . . . . . . . . . . . . . . . . . . . . . . 35

HISTORY . . . . . . . . . . . . . . . . . . . . . . . . . . . . . . . . . . . . . . . 35

CONTRIBUTIONS OF AUTHORS . . . . . . . . . . . . . . . . . . . . . . . . . . . . . . . . . . . . . . 35

DECLARATIONS OF INTEREST . . . . . . . . . . . . . . . . . . . . . . . . . . . . . . . . . . . . . $\quad . \quad 35$

SOURCES OF SUPPORT . . . . . . . . . . . . . . . . . . . . . . . . . . . . . . . . . . . . . . . . . . . . 35

DIFFERENCES BETWEEN PROTOCOL AND REVIEW . . . . . . . . . . . . . . . . . . . . . . . . . 36

INDEX TERMS . . . . . . . . . . . . . . . . . . . . . . . . . . . . . . . . . . . . . . . . . 36

Regular treatment with formoterol versus regular treatment with salmeterol for chronic asthma: serious adverse events (Review)

Copyright $(2012$ The Cochrane Collaboration. Published by John Wiley \& Sons, Ltd. 


\title{
[Intervention Review]
}

\section{Regular treatment with formoterol versus regular treatment with salmeterol for chronic asthma: serious adverse events}

\author{
Christopher J Cates ${ }^{1}$, Toby J Lasserson ${ }^{2}$ \\ ${ }^{1}$ Population Health Sciences and Education, St George's, University of London, London, UK. ${ }^{2}$ Cochrane Editorial Unit, The Cochrane \\ Collaboration, London, UK \\ Contact address: Christopher J Cates, Population Health Sciences and Education, St George's, University of London, Cranmer Terrace, \\ London, SW17 0RE, UK. ccates@sgul.ac.uk.
}

Editorial group: Cochrane Airways Group.

Publication status and date: New search for studies and content updated (no change to conclusions), published in Issue 3, 2012.

Review content assessed as up-to-date: 5 January 2012.

Citation: Cates CJ, Lasserson TJ. Regular treatment with formoterol versus regular treatment with salmeterol for chronic asthma: serious adverse events. Cochrane Database of Systematic Reviews 2012, Issue 3. Art. No.: CD007695. DOI: 10.1002/14651858.CD007695.pub3.

Copyright (C) 2012 The Cochrane Collaboration. Published by John Wiley \& Sons, Ltd.

\section{A B S T R A C T}

\section{Background}

An increase in serious adverse events with both regular formoterol and regular salmeterol in chronic asthma has been demonstrated in previous Cochrane reviews.

\section{Objectives}

We set out to compare the risks of mortality and non-fatal serious adverse events in trials which have randomised patients with chronic asthma to regular formoterol versus regular salmeterol.

Search methods

We identified trials using the Cochrane Airways Group Specialised Register of trials. We checked manufacturers' websites of clinical trial registers for unpublished trial data and also checked Food and Drug Administration (FDA) submissions in relation to formoterol and salmeterol. The date of the most recent search was January 2012.

\section{Selection criteria}

We included controlled, parallel-design clinical trials on patients of any age and with any severity of asthma if they randomised patients to treatment with regular formoterol versus regular salmeterol (without randomised inhaled corticosteroids), and were of at least 12 weeks' duration.

Data collection and analysis

Two authors independently selected trials for inclusion in the review and extracted outcome data. We sought unpublished data on mortality and serious adverse events from the sponsors and authors.

\section{Main results}

The review included four studies (involving 1116 adults and 156 children). All studies were open label and recruited patients who were already taking inhaled corticosteroids for their asthma, and all studies contributed data on serious adverse events. All studies compared formoterol $12 \mu \mathrm{g}$ versus salmeterol $50 \mu \mathrm{g}$ twice daily. The adult studies were all comparing Foradil Aerolizer with Serevent Diskus, 
and the children's study compared Oxis Turbohaler to Serevent Accuhaler. There was only one death in an adult (which was unrelated to asthma) and none in children, and there were no significant differences in non-fatal serious adverse events comparing formoterol to salmeterol in adults (Peto odds ratio (OR) 0.77; 95\% confidence interval (CI) 0.46 to 1.28 ), or children (Peto OR 0.95; $95 \%$ CI 0.06 to 15.33). Over a six-month period, in studies involving adults that contributed to this analysis, the percentages with serious adverse events were $5.1 \%$ for formoterol and $6.4 \%$ for salmeterol; and over a three-month period the percentages of children with serious adverse events were $1.3 \%$ for formoterol and $1.3 \%$ for salmeterol.

\section{Authors' conclusions}

We identified four studies comparing regular formoterol to regular salmeterol (without randomised inhaled corticosteroids, but all participants were on regular background inhaled corticosteroids). The events were infrequent and consequently too few patients have been studied to allow any firm conclusions to be drawn about the relative safety of formoterol and salmeterol. Asthma-related serious adverse events were rare and there were no reported asthma-related deaths.

\section{PLAIN LANGUAGE SUMMARY}

\section{Regular treatment with formoterol versus regular treatment with salmeterol in chronic asthma: serious adverse events}

Asthma is a common condition that affects the airways - the small tubes that carry air in and out of the lungs. When a person with asthma comes into contact with an irritant (an asthma trigger), the muscles around the walls of the airways tighten, the airways become narrower, and the lining of the airways becomes inflamed and starts to swell. This leads to the symptoms of asthma - wheezing, coughing and difficulty in breathing. They can lead to an asthma attack or exacerbation. People can have underlying inflammation in their lungs and sticky mucus or phlegm may build up, which can further narrow the airways. There is no cure for asthma; however there are medications that allow most people to control their asthma so they can get on with daily life.

Long-acting beta $a_{2}$-agonists, such as formoterol and salmeterol, work by reversing the narrowing of the airways that occurs during an asthma attack. These drugs - taken by inhaler - are known to improve lung function, symptoms, quality of life and reduce the number of asthma attacks. However, there are concerns about the safety of long-acting beta 2 -agonists, particularly in people who are not taking inhaled corticosteroids to control the underlying inflammation.

We did this review to take a closer look at the safety of people taking formoterol daily compared to salmeterol daily. All participants were prescribed regular background treatment with inhaled corticosteroids. We found three trials on 1116 adults and one trial on 156 children. There was not enough information to draw any conclusions on the relative safety of regular formoterol and regular salmeterol in chronic asthma, but serious asthma-related events were rare, and only one non-asthma-related death was reported. 


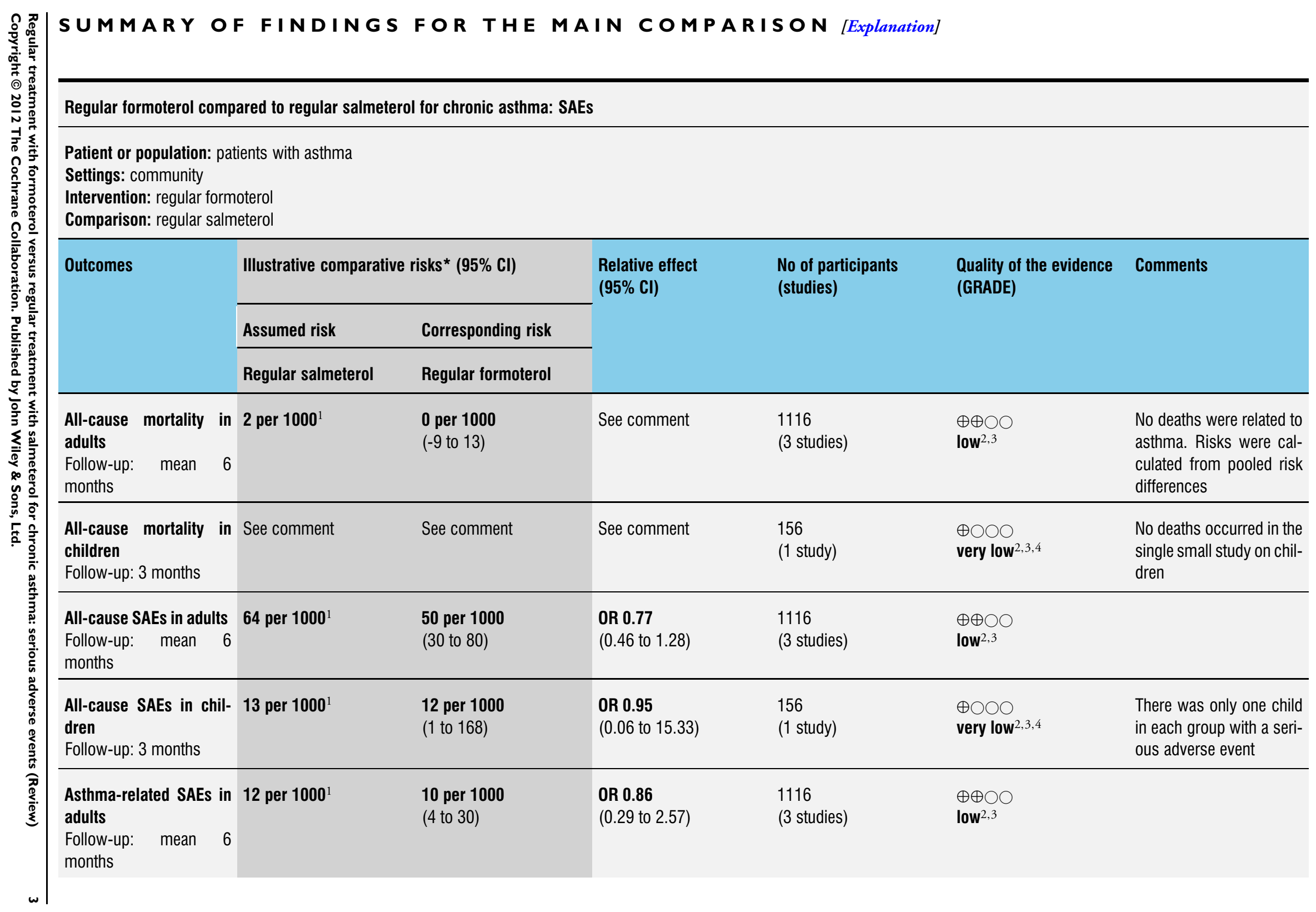




\begin{tabular}{|c|c|c|c|c|c|c|}
\hline $\begin{array}{l}\text { Asthma-related SAEs in } \\
\text { children } \\
\text { Follow-up: } 3 \text { months }\end{array}$ & See comment & See comment & Not estimable & $\begin{array}{l}156 \\
\text { (1 study) }\end{array}$ & $\begin{array}{l}\oplus \bigcirc \bigcirc \bigcirc \\
\text { very low }{ }^{2,3,4}\end{array}$ & $\begin{array}{l}\text { No asthma-related SAEs } \\
\text { in the single small study } \\
\text { on children }\end{array}$ \\
\hline
\end{tabular}

*The basis for the assumed risk (e.g. the median control group risk across studies) is provided in footnotes. The corresponding risk (and its $95 \%$ confidence interval) is based on the assumed risk in the comparison group and the relative effect of the intervention (and its $95 \% \mathrm{Cl}$ ).

Cl: Confidence interval; RR: Risk ratio; OR: Odds ratio; SAE: serious adverse event

GRADE Working Group grades of evidence

High quality: Further research is very unlikely to change our confidence in the estimate of effect.

Moderate quality: Further research is likely to have an important impact on our confidence in the estimate of effect and may change the estimate.

Low quality: Further research is very likely to have an important impact on our confidence in the estimate of effect and is likely to change the estimate.

Very low quality: We are very uncertain about the estimate.

Mean event rate in salmeterol arm of the included studies.

Unblinded studies.

Confidence intervals too wide to reach firm conclusions.

Only one small study found in children. 


\section{B A C K G R O U N D}

When patients with asthma are not controlled by low-dose inhaled corticosteroids alone, many asthma guidelines recommend additional long-acting beta 2 -agonists. Several Cochrane reviews have addressed the efficacy of long-acting beta 2 -agonists in addition to inhaled corticosteroids (Ni Chroinin 2005; Ni Chroinin 2009), in comparison with placebo (Walters 2007), short-acting beta 2 -agonists (Walters 2002), leukotriene-receptor antagonists (Ducharme 2006) and increased doses of inhaled corticosteroids (Greenstone 2005). The beneficial effects of long-acting beta 2 -agonists on lung function, symptoms, quality of life and exacerbations requiring oral steroids have been demonstrated. The pharmacology of beta 2 agonists is discussed in more detail in Appendix 1.

However, there is also longstanding controversy over the regular use of beta 2 -agonists in asthma. Sears 1986 suggested that excessive use of short-acting beta2-agonists might have contributed directly or indirectly to increases in asthma deaths in New Zealand between 1960 and 1980. The authors commented that "most deaths were associated with poor assessment, underestimation of severity and inappropriate treatment (over-reliance on bronchodilators and under use of systemic corticosteroids), and delays in obtaining help."

Concern remains that the symptomatic benefit from treatment with long-acting beta 2 -agonists might lead to underestimation of attack severity in acute asthma, and could lead to an increase in asthma-related deaths (as seen in SMART 2006). Furthermore, regular treatment with beta 2 -agonists can lead to tolerance to their bronchodilator effects and this phenomenon may be more marked with longer-acting as opposed to shorter-acting compounds (Lipworth 1997). A number of molecular mechanisms have been proposed to explain the possible detrimental effect of long-term beta 2 -agonist use in asthma, including desensitisation due to receptor down regulation with cellular internalisation (Giembycz 2006).

A recent systematic review of the effect of long-acting beta2-agonists on severe asthma exacerbations and asthma-related deaths (Salpeter 2006) concluded that "long-acting beta-agonists have been shown to increase severe and life-threatening asthma exacerbations, as well as asthma-related deaths". Salpeter 2006 only considered trials that compared long-acting beta 2 -agonists with placebo, and the review was not able to include 28 trials in the primary analysis (including nearly 6000 patients) because information was not provided for asthma-related deaths.

Currently there are two long-acting beta 2 -agonists available, salmeterol and formoterol (also known as eformoterol). These two drugs are known to have differences in speed of onset and receptor activity, and are used in different ways. Salmeterol has a slower onset of action than formoterol and is not used as relief medication, whereas formoterol can be used for maintenance and relief of symptoms. Not all beta 2 -agonists carry the same risks, as pointed out in the book entitled 'The Fenoterol Story' (Pearce
2007). Appendix 2 discusses the possible mechanisms of increased asthma mortality with beta-agonists in more detail.

Two published reviews have assessed the risk of serious adverse events (SAEs) with regular salmeterol (Cates 2008) and formoterol (Cates 2008a) without randomised inhaled corticosteroids in comparison to placebo or short-acting beta 2 -agonists, and further reviews have compared regular formoterol and salmeterol when randomised with an inhaled corticosteroid (Cates 2009; Cates 2009a; Cates 2011; Jaeschke 2008; Jaeschke 2008a).

There is a need to systematically review all the available data from controlled trials that have compared patients randomised to regular formoterol or regular salmeterol without randomised inhaled corticosteroids, although it is likely that such patients in trials would already be prescribed background treatment with inhaled corticosteroids. We considered all SAEs (fatal and non-fa$\mathrm{tal}$ ), whether or not these were deemed by the investigators to be related to trial medication.

\section{O B J E C T IVES}

To assess the risk of mortality and non-fatal SAEs in trials which have randomised patients with chronic asthma to regular formoterol versus regular salmeterol.

\section{METHODS}

\section{Criteria for considering studies for this review}

\section{Types of studies}

We included randomised trials (RCTs) of parallel design, with or without blinding, in which patients with chronic asthma were randomly assigned to regular treatment with formoterol versus salmeterol. We excluded studies on acute asthma and exerciseinduced bronchospasm.

\section{Types of participants}

We included patients with a clinical diagnosis of asthma of any age group, unrestricted by disease severity, previous or current treatment.

\section{Types of interventions}

We included trials that randomised patients to receive inhaled formoterol versus salmeterol given regularly for a period of at least 12 weeks, but not randomised with inhaled corticosteroids. We excluded studies that used adjustable maintenance dosing and single inhaler therapy (for maintenance and relief of symptoms). 


\section{Types of outcome measures}

Outcomes were not subdivided according to whether the trial investigators considered them to be related to trial medication.

\section{Primary outcomes}

1. All-cause mortality

2. All-cause non-fatal SAEs

\section{Secondary outcomes}

1. Asthma-related mortality

2. Asthma-related non-fatal SAEs

3. Cardiovascular-related mortality

An illustrative example of the definition of SAEs used in trials by GlaxoSmithKline is shown in Appendix 3

\section{Search methods for identification of studies}

\section{Electronic searches}

We identified trials using the Cochrane Airways Group Specialised Register of trials, which is derived from systematic searches of bibliographic databases including the Cochrane Central Register of Controlled Trials (CENTRAL), MEDLINE, EMBASE, CINAHL, AMED and PsycINFO, and handsearching of respiratory journals and meeting abstracts (please see Appendix 4 for further details). We searched all records in the Specialised Register coded as 'asthma' using the following terms:

(salmeterol or serevent) AND (formoterol or eformoterol or oxis or foradil) AND (serious or safety or surveillance or mortality or death or intubat* or adverse or toxicity or complications or tolerability)

In addition we carried out a further search just using the terms: (salmeterol or serevent) AND (formoterol or eformoterol or oxis or foradil).

We conducted the latest searches in January 2012.

\section{Searching other resources}

We checked reference lists of all primary studies and review articles for additional references. We also checked websites of clinical trial registers for unpublished trial data and checked FDA submissions in relation to formoterol.

\section{Data collection and analysis}

\section{Selection of studies}

Both review authors independently assessed studies identified in the literature searches by examining titles, abstract and keywords fields. We obtained studies that potentially fulfilled the inclusion criteria in full text. We independently assessed these full-text trial reports for inclusion. No disagreements occurred over the inclusion or exclusion of studies.

\section{Data extraction and management}

CJC extracted data using a prepared checklist and entered them into RevMan 5 (RevMan 2011). TL independently extracted the results. Data included characteristics of included studies (methods, participants, interventions, outcomes) and results of the included studies. We contacted authors and sponsors of included studies for unpublished adverse event data, and searched manufacturers' websites for further details of adverse events. We also searched FDA submissions. We recorded all-cause SAEs (fatal and nonfatal) and, in view of the difficulty in deciding whether events are asthma-related, we noted details of the cause of death and SAEs where they were available. We also sought the definition of SAEs.

\section{Assessment of risk of bias in included studies}

CJC assessed the included studies for bias protection (including sequence generation for randomisation, allocation concealment, blinding of participants and assessors, loss to follow-up, completeness of outcome assessment and other possible sources of bias), and this was independently verified by TL.

\section{Unit of analysis issues}

We extracted data using the number of participants who suffered one or more SAEs, in order to avoid double-counting events from the same participant.

\section{Assessment of heterogeneity}

We assessed heterogeneity in the pooled odds ratio using the $\mathrm{I}^{2}$ statistic in RevMan 5 to indicate how much of the total heterogeneity found was between, rather than within, studies.

\section{Data synthesis}

The outcomes of this review were dichotomous and we recorded the number of participants with each outcome event by allocated treated group. We calculated pooled odds ratio $(\mathrm{OR})$ and risk difference (RD). The Peto OR has advantages when events are rare, as no adjustment for zero cells is required. This property was found in previous reviews to be more important than potential problems with unbalanced treatment arms and large effect sizes, and we therefore calculated the results for SAEs in RevMan 5 using the Peto method with the Mantel-Haenszel method for sensitivity analysis. We could not use funnel plots to assess publication bias, as very few trials were identified. 


\section{Subgroup analysis and investigation of heterogeneity}

We planned to compare subgroups using tests for interaction (Altman 2003). However, events were too sparse to allow a meaningful comparison of the results in adults and children, and background non-randomised use of inhaled corticosteroids was used in all studies, so subgroup analysis by background inhaled corticosteroid use was not possible.

\section{Sensitivity analysis}

We performed sensitivity analysis to assess the impact of the method used to combine the study events (risk difference, Peto OR and Mantel-Haenszel OR). The degree of bias protection in the study designs was part of planned sensitivity analysis, but all the studies were of open design and reporting of sequence generation and allocation concealment was poor.

\section{R E S U L T S}

\section{Description of studies}

See: Characteristics of included studies; Characteristics of excluded studies.

\section{Results of the search}

We carried out the original search in January 2009 and identified 40 references (155 references without the adverse event filter). We identified three studies for inclusion (Condemi 2001; Everden 2004; Vervloet 1998) from the shorter list of references. When this was rechecked against the unfiltered list we identified one further study (Gabbay 1998), which had been published in abstract form only in 1998, and found four further references related to the three included studies. We identified 13 further studies for possible inclusion, but we excluded them after more detailed inspection (see Characteristics of excluded studies).

We carried out an updated search in January 2012 but there were no new studies included.

\section{Included studies}

Of the four included studies, three enrolled a combined total of 1137 adults (Condemi 2001; Gabbay 1998; Vervloet 1998), and one enrolled 156 children (Everden 2004). Vervloet 1998 included adults with reversible airways obstruction, and whilst they did not seek to exclude participants with chronic obstructive pulmonary disease (COPD), they indicated that most participants suffered from asthma, so both review authors independently decided that this study should be included.

All the studies compared a twice daily dose of formoterol $12 \mu \mathrm{g}$ with twice daily salmeterol $50 \mu \mathrm{g}$. Condemi 2001, Gabbay 1998 and Vervloet 1998 compared the Foradil Aerolizer with Serevent Diskus inhaler devices, whilst Everden 2004 compared the Oxis Turbohaler with Serevent Accuhaler. Although none of the studies randomised patients to inhaled corticosteroids (in the form of combined inhalers), all four studies randomised patients who were already taking inhaled corticosteroids as background treatment. All the studies were multi-centre, open (i.e. unblinded), parallelgroup design.

Condemi 2001, Gabbay 1998 and Vervloet 1998 were sponsored by Novartis (manufacturer of Foradil) and Everden 2004 was sponsored by AstraZeneca (manufacturer of Oxis).

\section{Risk of bias in included studies}

\section{Allocation}

Few details were available in relation to sequence generation or allocation concealment. As all the studies were sponsored by Novartis or AstraZeneca it is likely that they were adequately protected from the risk of selection bias.

\section{Blinding}

All the studies were open-label in design, so unprotected against performance bias. We remain uncertain as to the impact of this on the outcomes primarily of interest to this review.

\section{Incomplete outcome data}

The adult studies had low dropout rates, but the study in children had higher dropout rates and these were not balanced between the trial arms. Thirty-three out of 127 children discontinued the study (formoterol 21, salmeterol 12). All children who took at least one dose of medication were included in the analysis.

\section{Selective reporting}

No serious adverse event data were published in the abstract of Gabbay 1998, and no full publication has been identified after correspondence with the author, who was unable to offer further information. Vervloet 1998 also included information on all adverse events only, but no separate data on SAEs. Novartis have been able to provide data on file for SAEs in both of these studies. An overview of the risks of bias is shown in Figure 1. 
Figure I. Methodological quality summary: review authors' judgements about each methodological quality item for each included study.

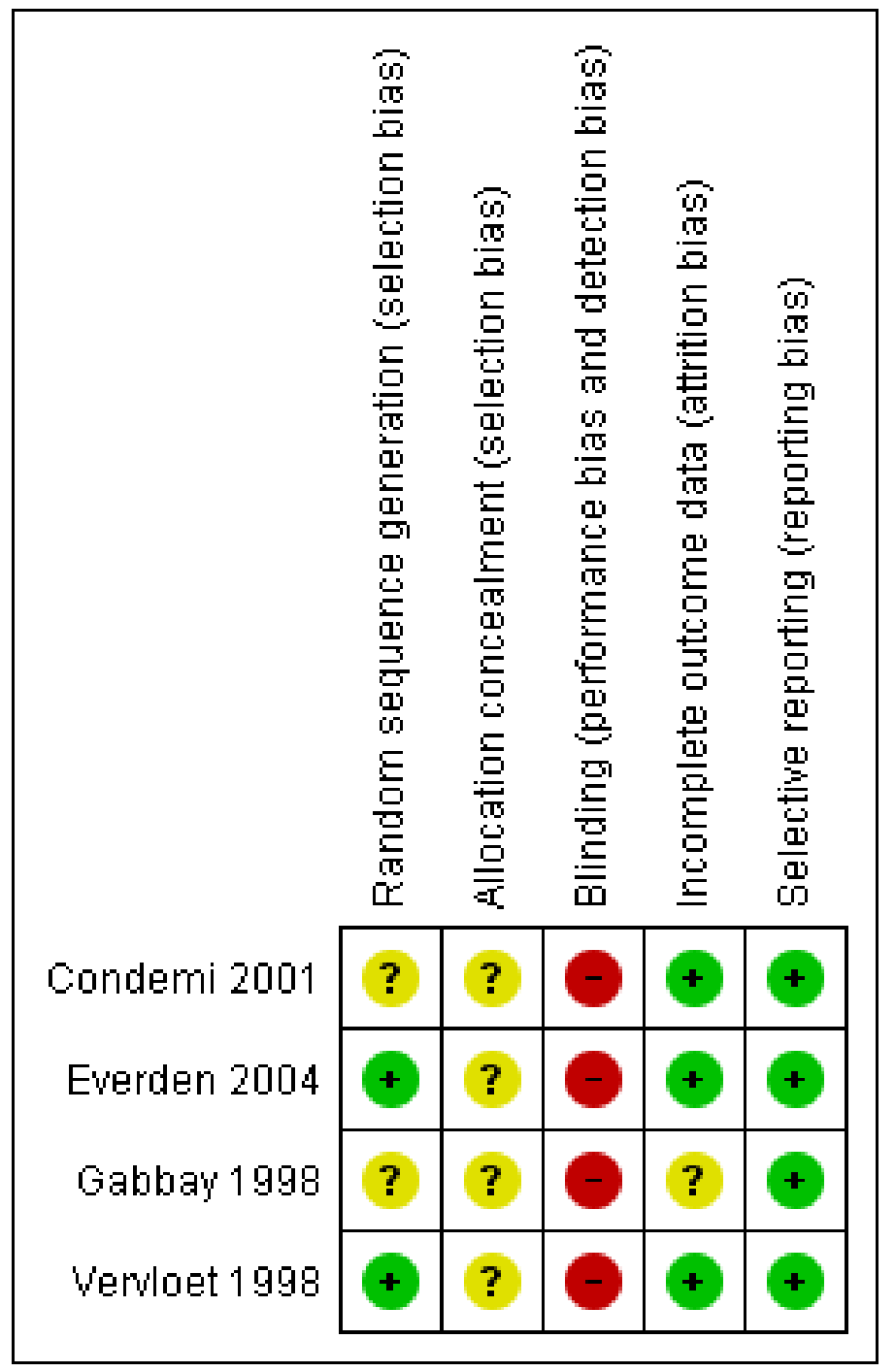

\section{Effects of interventions}

See: Summary of findings for the main comparison Regular formoterol compared to regular salmeterol for chronic asthma: serious adverse events

All studies have contributed serious adverse event data to this review: Condemi 2001 (528 adults studied for six months) and Everden 2004 (156 children studies for three months) from published papers and Gabbay 1998 (127 adults for three months) and Vervloet 1998 (482 adults for six months) from data on file at Novartis.

\section{All-cause mortality}

No deaths were reported in 528 adults in Condemi 2001. Novartis have confirmed that there were no deaths in Gabbay 1998, and in Vervloet 1998 there was one participant who died of heart disease following coronary surgery in the salmeterol group. AstraZeneca have confirmed that there were no deaths in the 156 children in Everden 2004. There are insufficient data to draw any firm conclusions in relation to mortality, but using the pooled risk difference (RD) to combine the results of studies, the overall risk difference in adults (RD -0.00; 95\% confidence interval (CI) 0.01 to 0.01 ) and in children (RD $0.00 ; 95 \% \mathrm{CI}-0.02$ to 0.02 ) is 
as shown in Figure 2. This indicates that the maximum absolute difference between treatments in adults who have been studied is one percentage point either way, and in children is two percentage points either way. This range of uncertainty needs to be considered in the context of a mortality rate of $0.05 \%$ found in studies on formoterol alone (Cates 2008a).

Figure 2. Forest plot of comparison: I Regular formoterol versus regular salmeterol, outcome: I.I Allcause mortality.

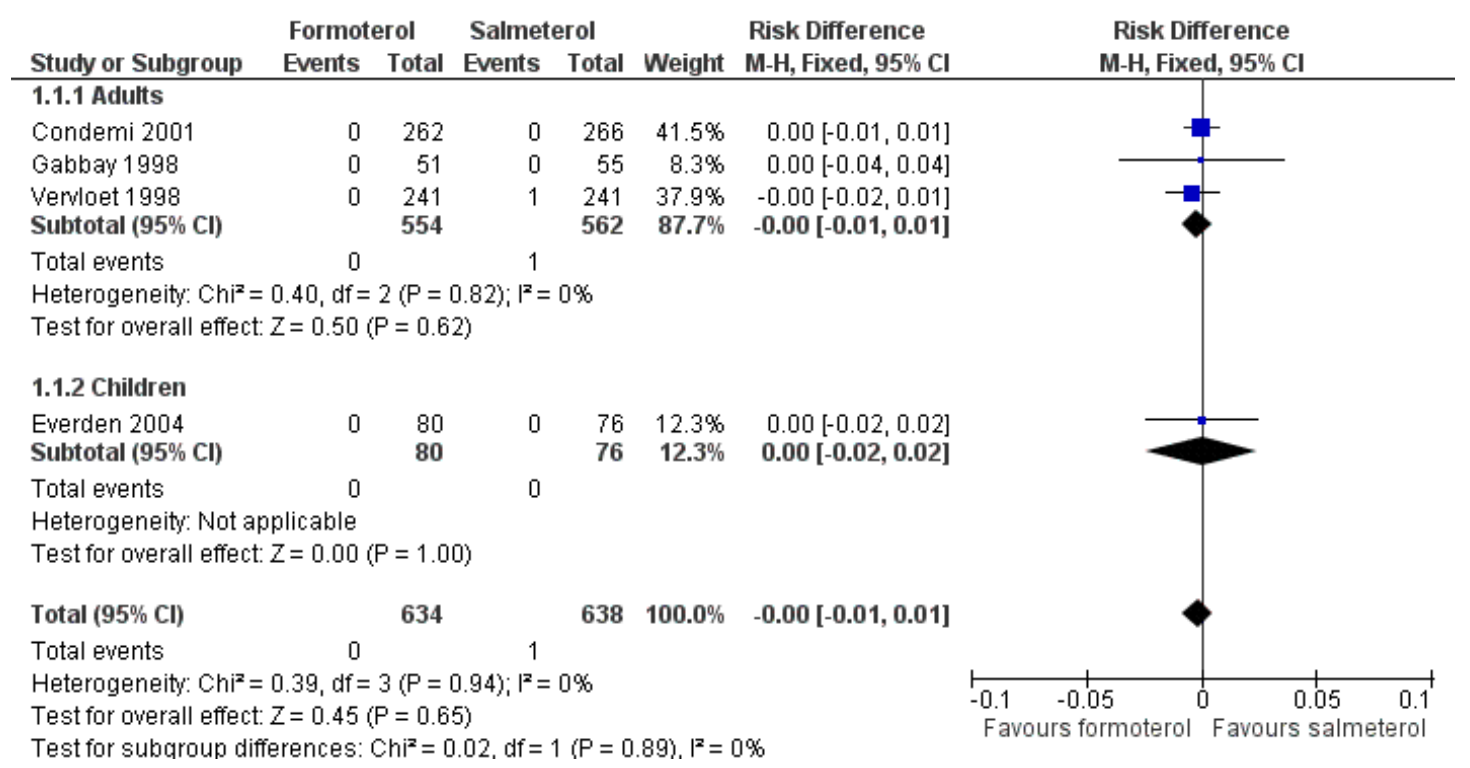

\section{All-cause non-fatal serious adverse events (SAEs)}

\section{Adults}

Condemi 2001 reported nine out of 262 adults having SAEs on formoterol and 15 out of 266 on salmeterol, and in Vervloet 1998 there were non-fatal SAEs in 19 of 241 adults on formoterol and 21 out of 241 adults on salmeterol (Novartis data on file). Gabbay 1998 recorded only one patient with a serious adverse event (an asthma exacerbation); the patient was not included in the safety analysis for this trial as it could not be confirmed that any of the study drug (salmeterol) had been taken. The Peto odds ratio (OR) comparing formoterol to salmeterol was not significantly different between groups (Peto OR 0.77; 95\% CI 0.46 to 1.28 (Figure 3)), nor was the risk difference (RD $-0.01 ; 95 \% \mathrm{CI}-0.04$ to 0.01 ). Over the six-month period for adults that contributed to this analysis the percentages of adults with SAEs were formoterol $5.1 \%$ and salmeterol $6.4 \%$. 
Figure 3. Forest plot of comparison: I Regular formoterol versus regular salmeterol, outcome: I.2 Allcause SAEs.

\begin{tabular}{|c|c|c|c|c|c|c|c|c|}
\hline Study or Subgroup & $\begin{array}{l}\text { Formot } \\
\text { Events }\end{array}$ & $\begin{array}{l}\text { rol } \\
\text { Total }\end{array}$ & $\begin{array}{l}\text { Salmet } \\
\text { Events }\end{array}$ & $\begin{array}{l}\text { erol } \\
\text { Total }\end{array}$ & Weight & $\begin{array}{l}\text { Peto Odds Ratio } \\
\text { Peto, Fixed, } 95 \% \text { Cl }\end{array}$ & $\begin{array}{c}\text { Peto Odds Ratio } \\
\text { Peto, Fixed, } 95 \% \mathrm{Cl}\end{array}$ & \\
\hline \multicolumn{9}{|c|}{ - } \\
\hline Condemi 2001 & 9 & 262 & 15 & 266 & $37.2 \%$ & $0.60[0.27,1.37]$ & & \\
\hline Gabbay 1998 & 0 & 51 & 0 & 55 & & Not estimable & & \\
\hline $\begin{array}{l}\text { Vervloet } 1998 \\
\text { Subtotal (95\% Cl) }\end{array}$ & 19 & $\begin{array}{l}241 \\
554\end{array}$ & 21 & $\begin{array}{l}241 \\
562\end{array}$ & $\begin{array}{l}59.6 \% \\
96.8 \%\end{array}$ & $\begin{array}{r}0.90[0.47,1.71] \\
\mathbf{0 . 7 7}[\mathbf{0 . 4 6 , 1 . 2 8}]\end{array}$ & & \\
\hline \multicolumn{9}{|c|}{$\begin{array}{l}\text { Heterogeneity: } \text { Chi }^{2}=0.56, d f=1(P=0.45) ;\left.\right|^{2}=0 \% \\
\text { Test for overall effect: } Z=1.01(P=0.31)\end{array}$} \\
\hline \multicolumn{9}{|l|}{ 1.2.2 Children } \\
\hline $\begin{array}{l}\text { Everden } 2004 \\
\text { Subtotal }(95 \% \mathrm{Cl})\end{array}$ & 1 & $\begin{array}{l}80 \\
80\end{array}$ & 1 & $\begin{array}{l}76 \\
76\end{array}$ & $\begin{array}{l}3.2 \% \\
3.2 \%\end{array}$ & $\begin{array}{r}0.95[0.06,15.33] \\
\mathbf{0 . 9 5}[\mathbf{0 . 0 6}, \mathbf{1 5 . 3 3}]\end{array}$ & & \\
\hline \multicolumn{9}{|c|}{$\begin{array}{l}\text { Heterogeneity: Not applicable } \\
\text { Test for overall effect: } Z=0.04(P=0.97)\end{array}$} \\
\hline Total $(95 \% \mathrm{Cl})$ & & 634 & & 638 & $100.0 \%$ & $0.77[0.47,1.28]$ & & \\
\hline Total events & 29 & & 37 & & & & & \\
\hline $\begin{array}{l}\text { Heterogeneity: } \mathrm{Chi}^{2}= \\
\text { Test for overall effect } \\
\text { Test for subqroup dit }\end{array}$ & $\begin{array}{l}0.58, \mathrm{df}= \\
Z=1.00 \\
\text { erences: }\end{array}$ & $\begin{array}{l}2(P=0 \\
P=0.3 \\
C h i^{2}=0\end{array}$ & $\begin{array}{l}.75) ; 1^{2}= \\
\text { 2) } \\
.02, d f=\end{array}$ & $0 \%$ & 88), $\left.\right|^{2}=$ & & 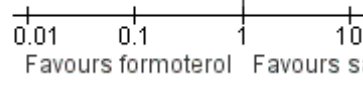 & $\begin{aligned} 100 \\
\text { eterol }\end{aligned}$ \\
\hline
\end{tabular}

We performed a sensitivity analysis to assess the addition of the patient from Gabbay 1998 and this gave very similar results (Peto OR 0.75 ; $95 \%$ CI 0.45 to 1.24$)$. The OR was also virtually unchanged using Mantel-Haenszel random (OR 0.77; 95\% CI 0.46 to 1.29 ) or fixed method (OR 0.77; 95\% CI 0.46 to 1.28 ).

CI -0.04 to 0.04$)$.

\section{Asthma-related SAEs}

\section{Children}

Everden 2004 reported one out of 80 children experiencing SAEs on formoterol and one out of 76 children on salmeterol. Over the three-month period the percentages of children with SAEs were formoterol $1.3 \%$ and salmeterol $1.3 \%$. The Peto OR was not significantly different between groups (Peto OR 0.96; 95\% CI 0.06 to 15.52 ), nor was the risk difference (RD - 0.0005 ; $95 \%$

\section{Adults}

Of all the SAEs reported in Condemi 2001, two adults on formoterol and three adults on salmeterol were classified as having events related to asthma. In Vervloet 1998 there were four adults in each group with events related to asthma. Again there is no significant difference between the treatment groups (Peto OR 0.86; 95\% CI 0.29 to 2.57 (Figure 4)). 
Figure 4. Forest plot of comparison: I Regular formoterol versus regular salmeterol, outcome: I.3 Asthmarelated SAEs.

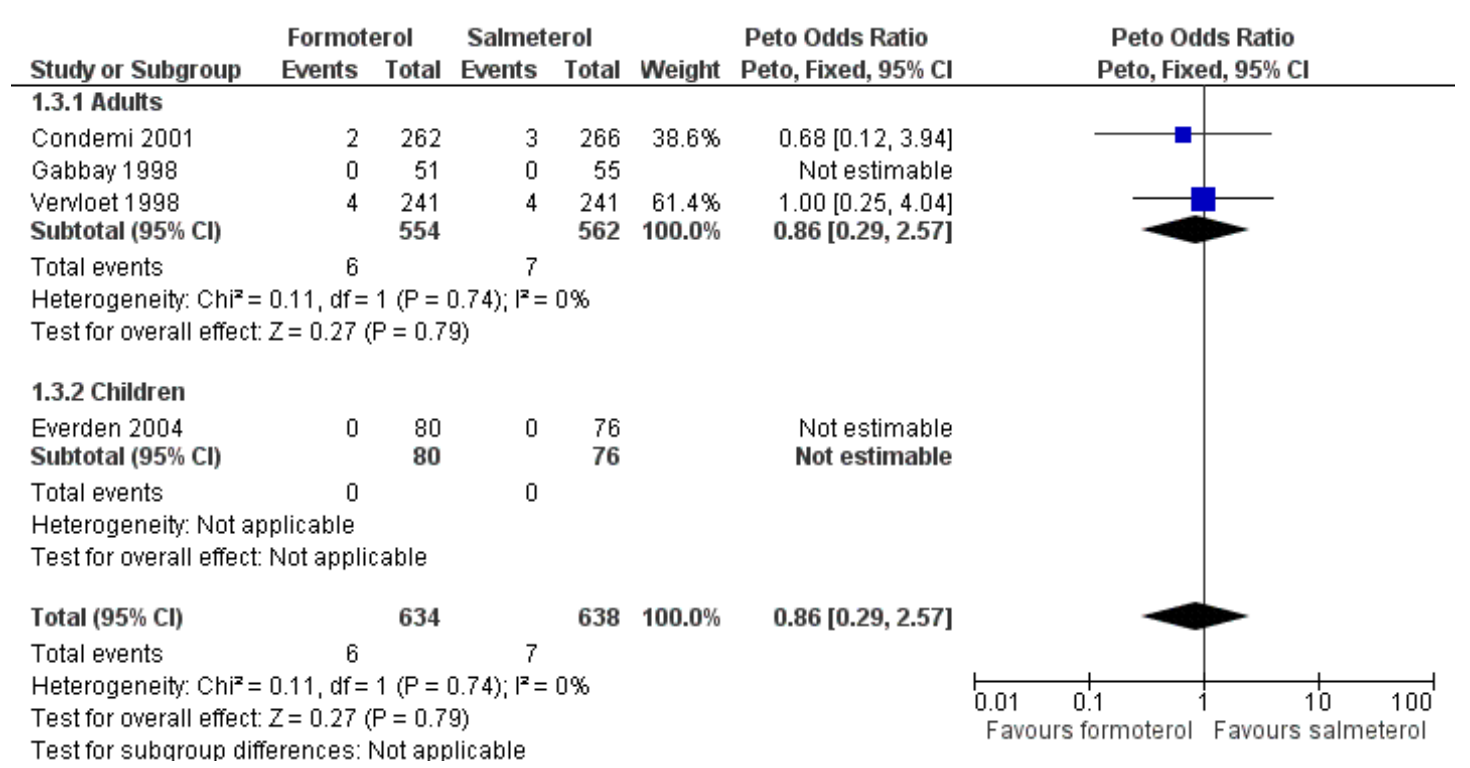

Sensitivity analysis to include the additional patient in Gabbay 1998 again gave very similar pooled results (Peto OR 0.76; 95\% CI 0.26 to 2.17).

\section{Children}

Neither of the SAEs in children in Everden 2004 were asthmarelated.

\section{ISCUSSION}

\section{Summary of main results}

We identified only three studies involving adults $(\mathrm{N}=1116)$ and one study in children $(\mathrm{N}=155)$ for inclusion in this review. Serious adverse events (SAEs) were rare, especially those related to asthma. Only one non-asthma-related death occurred. No significant differences in SAEs were found between regular formoterol and regular salmeterol in adults or children with asthma. All of the participants enrolled were taking inhaled corticosteroids at baseline.

\section{Overall completeness and applicability of evidence}

All of the studies enrolled patients who were already taking inhaled corticosteroids. Therefore it has not been possible to assess the

relative safety of formoterol and salmeterol in patients who were not prescribed background inhaled corticosteroids, but this is no longer considered acceptable practice.

\section{Quality of the evidence}

No double-blind trials have been carried out comparing regular formoterol with regular salmeterol. The open studies included in this review could have been influenced by the fact that the participants and investigators were aware of the assigned treatment for each patient, especially in studies sponsored by the companies marketing one of the comparator medications.

\section{Potential biases in the review process}

Data on SAEs have been obtained for all of the included studies.

\section{Agreements and disagreements with other studies or reviews}

Our two previous reviews (Cates 2008; Cates 2008a) indicated an increase in all-cause SAEs when both regular formoterol and regular salmeterol were compared with placebo. It would require very large numbers of patients in head-to-head comparison trials to determine whether there is any difference in SAEs between regular formoterol and salmeterol, and it is perhaps not surprising that it 
has not been possible to draw conclusions from this review, as the number of participants in the included trials is relatively small.

\section{AUTHORS, CONCLUSIONS}

\section{Implications for practice}

Four unblinded studies have been identified comparing regular formoterol to regular salmeterol. SAEs were infrequent and consequently too few patients have been studied to allow firm conclusions to be drawn. Asthma-related SAEs were rare and there were no reported asthma-related deaths.

\section{Implications for research}

In order to compare the safety of regular formoterol and regular salmeterol, much larger surveillance studies would need to be car- ried out. Ideally these should be double-blind, double-dummy, parallel-group studies.

A further review compares regular formoterol and salmeterol when randomised together with additional inhaled corticosteroids (Cates 2011).

\section{ACKNOWLEDGEMENTS}

We acknowledge the assistance of Susan Hansen in obtaining the papers and extracting study details, Elizabeth Stovold for assistance with the update searches and of Matthew Cates with the protocol, and for input re physiology of beta-agonist receptors. We thank Prof Haydn Walters for providing editorial review and we thank Linda Armstrong from Novartis for providing data on file for Vervloet 1998 and Gabbay 1998, and Joe Gray of AstraZeneca and Dr Everden for clarifying that there were no deaths in Everden 2004.

\section{R E F E R E N C E S}

\section{References to studies included in this review}

Condemi 2001 \{published data only\}

Condemi JJ. Comparison of the efficacy of formoterol and salmeterol in patients with reversible obstructive airway disease: a multicenter, randomized, open-label trial. Clinical Therapeutics 2001; Vol. 23, issue 9:1529-41.

\section{Everden 2004 \{published data only\}}

Everden P, Campbell M, Harnden C, McGoldrick H, Bodalia B, Manion V, et al.Eformoterol Turbohaler compared with salmeterol by dry powder inhaler in asthmatic children not controlled on inhaled corticosteroids. Pediatric Allergy and Immunology 2004; Vol. 15, issue 1: 40-7.

Everden P, Lloyd A, Hutchinson J, Plumb J. Costeffectiveness of eformoterol Turbohaler versus salmeterol Accuhaler in children with symptomatic asthma. Respiratory Medicine 2002; Vol. 96, issue 4:250-8. Everden P, Reynia S, Lloyd AC, Hutchinson JL, Plumb JM. Economic evaluation of eformoterol compared with salmeterol in children aged 6-17 with symptomatic asthma in the UK: cost-effectiveness results of the FACT study. European Respiratory Journal 2001; Vol. 18, issue Suppl $33: 122 s$.

\section{Gabbay 1998 \{published data only\}}

Gabbay MB, Kane H, di Benedetto G. A comparison of formoterol and salmeterol dry powders in the treatment of nocturnal asthma [abstract]. European Respiratory Journal. Supplement. 1998; Vol. 12, issue Suppl 28:325S.
Vervloet 1998 \{published data only\}

Rutten van Molken MP, van Doorslaer EK, Till MD. Costeffectiveness analysis of formoterol versus salmeterol in patients with asthma. Pharmacoeconomics 1998; Vol. 14, issue 6:671-84.

Sanguinetti CM, Duce F, Quebe Fehling E, Della Cioppa G, Di Benedetto G. A 6-month open comparison between formoterol and salmeterol dry powders in patients with reversible obstructive airway disease. European Respiratory Journal 1997; Vol. 10, issue Suppl 25:241S.

Vervloet D, Ekstrom T, Pela R, Duce Gracia F, Kopp C, Silvert BD, et al.A 6-month comparison between formoterol and salmeterol in patients with reversible obstructive airways disease. Respiratory Medicine 1998; Vol. 92, issue 6:836-42.

\section{References to studies excluded from this review}

\section{Brambilla 2003 \{published data only\}}

Brambilla C, Le Gros V, Bourdeix I. Formoterol 12 mug BID administered via single-dose dry powder inhaler in adults with asthma suboptimally controlled with salmeterol or on-demand salbutamol: a multicenter, randomized, open-label, parallel-group study. Clinical Therapeutics 2003; Vol. 25, issue 7:2022-36.

\section{Campbell 1999 \{published data only\}} Campbell LM, Anderson TJ, Parashchak MR, Burke CM, Watson SA, Turbitt ML. A comparison of the efficacy of long-acting beta 2-agonists: eformoterol via Turbohaler and salmeterol via pressurized metered dose inhaler or Accuhaler, in mild to moderate asthmatics. [Force Research Group corrected and republished with original paging, 
article originally printed in Respiratory Medicine 1999 Apr; 934:236-44]. Respiratory Medicine 1999; Vol. 93, issue 7: $236-44$.

\section{Eryonucu 2005 \{published data only\}}

Eryonucu B, Uzun K, Guler N, Tuncer M, Sezgi C. Comparison of the short-term effects of salmeterol and formoterol on heart rate variability in adult asthmatic patients. Chest 2005; Vol. 128, issue 3:1136-9.

Heijerman 1999 \{published data only\}

Heijerman HG, Dekker FW, Rammeloo RH, Roldaan AC, Sinninghe HE. Similar efficacy of formoterol via turbuhaler and salmeterol via diskhaler in the treatment of asthma. European Respiratory Society; 1999 Oct 9-13; Madrid, Spain 1999:[P2209].

\section{Larsson 1990 \{published data only\}}

Larsson S. Long-term studies on long-acting sympathomimetics. Lung 1990; Vol. 168, issue Suppl: $22-4$.

\section{Lemaigre 2006 \{published data only\}}

Lemaigre V, Van den Bergh O, Smets A, De Peuter S, Verleden GM. Effects of long-acting bronchodilators and placebo on histamine-induced asthma symptoms and mild bronchus obstruction. Respiratory Medicine 2006; Vol. 100 , issue 2:348-53.

\section{Novartis 2005 \{published data only\}}

Novartis. A 12-month multicenter, randomized, doubleblind, double-dummy trial to examine the long-term tolerability of formoterol $10 \mu \mathrm{g}$ via the multiple dose dry powder inhaler (MDDPI), both as twice daily maintenance therapy and as on-demand use in addition to maintenance in patients with persistent asthma. http:// pharma.us.novartis.com/ 2005.

Pohunek 2004 \{published data only\}

Pohunek P, Matulka M, Rybnicek O, Kopriva F, Honomichlova H, Svobodova T. Dose-related efficacy and safety of formoterol (Oxis) Turbuhaler compared with salmeterol Diskhaler in children with asthma. Pediatric Allergy and Immunology 2004; Vol. 15:32-9.

\section{Sill 1999 \{published data only\}}

Sill V, Bartuschka B, Villiger B, Ortland C, Domej W. Changes in specific airway resistance after powder inhalation of formoterol or salmeterol in moderate bronchial asthma. Pneumologie 1999; Vol. 53, issue 1:4-9.

van der Woude 2004 \{published data only\} van der Woude HJ, Postma DS, Politiek MJ, Winter $\mathrm{TH}$, Aalbers R. Relief of dyspnoea by beta2-agonists after methacholine-induced bronchoconstriction. Respiratory Medicine 2004; Vol. 98, issue 9:816-20.

van Veen 2003 \{published data only\}

van Veen A, Weller FR, Wierenga EA, Jansen HM, Jonkers RE. A comparison of salmeterol and formoterol in attenuating airway responses to short-acting beta2-agonists. Pulmonary Pharmacology and Therapeutics 2003; Vol. 16, issue 3:153-61.
Verini 1998 \{published data only\}

Verini M, Verrotti A, Greco R, Chiarelli F. Comparison of the bronchodilator effect of inhaled short- and longacting beta2-agonists in children with bronchial asthma. A randomised trial. Clinical Drug Investigation 1998; Vol. 16 , issue 1:19-24.

Von Berg 2003 \{published data only\}

Von Berg A, Papageorgiou Saxoni F, Wille S, Carrillo T, Kattamis C, Helms PJ. Efficacy and tolerability of formoterol Turbuhaler in children. International Journal of Clinical Practice 2003; Vol. 57:852-6.

\section{Additional references}

Altman 2003

Altman DG, Bland JM. Statistics notes: interaction revisited: the difference between two estimates. BMJ 2003; 326(7382):219.

\section{Anderson 2006}

Anderson GP. Current issues with beta(2)-adrenoceptor agonists - pharmacology and molecular and cellular mechanisms. Clinical Reviews in Allergy and Immunology 2006; Vol. 31, issue 2-3:119-30.

\section{Arnold 1985}

Arnold JMO, O'Connor PC, Riddell JG, Harron DWG, Shanks RG, McDevitt DG. Effects of the beta-2adrenoceptor antagonist ici-118,551 on exercise tachycardia and isoprenaline-induced beta-adrenoceptor responses in man. British Journal of Clinical Pharmacology 1985; Vol. 19 , issue 5:619-30.

\section{Barnes 1993}

Barnes PJ. Beta-adrenoceptors on smooth-muscle, nerves and inflammatory cells. Life Sciences 1993; Vol. 52, issue 26:2101-9.

Barnes 1995

Barnes PJ. Beta-adrenergic receptors and their regulation. American Journal of Respiratory and Critical Care Medicine 1995; Vol. 152, issue 3:838-60.

\section{Bennett 1994}

Bennett JA, Smyth ET, Pavord ID, Wilding PJ, Tattersfield AE. Systemic effects of salbutamol and salmeterol in patients with asthma. Thorax 1994; Vol. 49, issue 8:771-4.

\section{Bijl-Hofland 2001}

Bijl-Hofland ID, Cloosterman SG, Folgering HT, van den Elshout FJ, van Weel C, van Schayck CP. Inhaled corticosteroids, combined with long-acting beta(2)-agonists, improve the perception of bronchoconstriction in asthma. American Journal of Respiratory and Critical Care Medicine 2001; Vol. 164, issue 5:764-9.

\section{Blauw 1995}

Blauw GJ, Westendorp RGJ. Asthma deaths in New

Zealand - whodunnit. The Lancet 1995;345:2-3.

\section{Brown 1983}

Brown MJ, Brown DC, Murphy MB. Hypokalemia from beta-2-receptor stimulation by circulating epinephrine. New England Journal of Medicine 1983; Vol. 309, issue 23:1414-9. 
Burgess 1991

Burgess CD, Windom HH, Pearce N, Marshall S, Beasley R, Siebers RWL, et al.Lack of evidence for beta-2 receptor selectivity - a study of metaproterenol, fenoterol, isoproterenol, and epinephrine in patients with asthma. American Review of Respiratory Disease 1991; Vol. 143, issue 2:444-6.

Burggraaf 2001

Burggraaf J, Westendorp RGJ, in't Veen J, Schoemaker RC Sterk PJ, Cohen AF, et al.Cardiovascular side effects of inhaled salbutamol in hypoxic asthmatic patients. Thorax 2001; Vol. 56, issue 7:567-9.

\section{Cates 2008}

Cates CJ, Cates MJ. Regular treatment with salmeterol for chronic asthma: serious adverse events. Cochrane Database of Systematic Reviews 2008, Issue 3. [DOI: 10.1002/ 14651858.CD006363.pub2]

\section{Cates 2008a}

Cates CJ, Cates MJ, Lasserson TJ. Regular treatment with formoterol for chronic asthma: serious adverse events. Cochrane Database of Systematic Reviews 2008, Issue 4. [DOI: 10.1002/14651858.CD006923.pub2]

\section{Cates 2009}

Cates CJ, Lasserson TJ, Jaeschke R. Regular treatment with formoterol and inhaled steroids for chronic asthma: serious adverse events. Cochrane Database of Systematic Reviews 2009, Issue 2. [DOI: 10.1002/ 14651858.CD006924.pub2]

\section{Cates 2009a}

Cates CJ, Lasserson TJ, Jaeschke R. Regular treatment with salmeterol and inhaled steroids for chronic asthma: serious adverse events. Cochrane Database of Systematic Reviews 2009, Issue 3. [DOI: 10.1002/ 14651858.CD006922.pub2]

\section{Cates 2011}

Cates CJ, Lasserson TJ. Regular treatment with formoterol and an inhaled corticosteroid versus regular treatment with salmeterol and an inhaled corticosteroid for chronic asthma: serious adverse events. Cochrane Database of Systematic Reviews 2011, Issue 12. [DOI: 10.1002/ 14651858.CD007694.pub2]

\section{Cockcroft 1993}

Cockcroft DW, McParland CP, Britto SA, Swystun VA, Rutherford BC. Regular inhaled salbutamol and airway responsiveness to allergen. Lancet 1993; Vol. 342, issue 8875:833-7.

\section{Collins 1969}

Collins JM, McDevitt DG, Shanks RG, Swanton JG. Cardio-toxicity of isoprenaline during hypoxia. British Journal of Pharmacology 1969; Vol. 36, issue 1:35-7.

\section{Crane 1989}

Crane J, Pearce N, Flatt A, Burgess C, Jackson R, Kwong $\mathrm{T}$, et al.Prescribed fenoterol and death from asthma in New Zealand, 1981-83 - case-control study. Lancet 1989; Vol. 1 , issue 8644:917-22.

\section{Ducharme 2006}

Ducharme FM, Lasserson TJ, Cates CJ. Addition to inhaled corticosteroids of long-acting beta2-agonists versus anti-leukotrienes for chronic asthma. Cochrane Database of Systematic Reviews 2011, Issue 8. [DOI: 10.1002/ 14651858.CD003137.pub3]

\section{Giembycz 2006}

Giembycz MA, Newton R. Beyond the dogma: novel B2adrenoceptor signalling in the airways. European Respiratory Journal 2006;27(6):1286-306.

\section{Grainger 1991}

Grainger J, Woodman K, Pearce N, Crane J, Burgess C, Keane A, et al.Prescribed fenoterol and death from asthma in New Zealand, 1981-7 - a further case-control study. Thorax 1991; Vol. 46, issue 2:105-11.

\section{Greenstone 2005}

Greenstone IR, Ni Chroinin M, Masse V, Danish A, Magdalinos $\mathrm{H}$, Zhang X, et al.Combination of inhaled long-acting beta2-agonists and inhaled steroids versus higher dose of inhaled steroids in children and adults with persistent asthma. Cochrane Database of Systematic Reviews 2005, Issue 4. [DOI: 10.1002/14651858.CD005533]

\section{Guhan 2000}

Guhan AR, Cooper S, Oborne J, Lewis S, Bennett J, Tattersfield AE. Systemic effects of formoterol and salmeterol: a dose-response comparison in healthy subjects. Thorax 2000; Vol. 55, issue 8:650-6.

\section{Hall 1989}

Hall JA, Petch MC, Brown MJ. Intracoronary injections of salbutamol demonstrate the presence of functional beta-2adrenoceptors in the human-heart. Circulation Research 1989; Vol. 65, issue 3:546-53.

\section{Hanania 2002}

Hanania NA, Sharfkhaneh A, Barber R, Dickey BF. Betaagonist intrinsic efficacy - measurement and clinical significance. American Journal of Respiratory and Critical Care Medicine 2002; Vol. 165, issue 10:1353-8.

\section{Hanania 2007}

Hanania NA, Moore RH, Zimmerman JL, Miller CT, Bag $\mathrm{R}$, Sharafkhaneh A, et al.The role of intrinsic efficacy in determining response to beta(2)-agonist in acute severe asthma. Respiratory Medicine 2007; Vol. 101, issue 5: 1007-14.

\section{Hancox 1999}

Hancox RJ, Aldridge RE, Cowan JO, Flannery EM, Herbison GP, McLachlan CR, et al.Tolerance to betaagonists during acute bronchoconstriction. European Respiratory Journal 1999; Vol. 14, issue 2:283-7.

\section{Hancox 2006a}

Hancox RJ. Concluding remarks: can we explain the association of beta-agonists with asthma mortality? A hypothesis. Clinical Reviews in Allergy and Immunology 2006; Vol. 31, issue 2-3:279-88. [1080-0549: (Print)] 


\section{Haney 2006}

Haney S, Hancox RJ. Recovery from bronchoconstriction and bronchodilator tolerance. Clinical Reviews in Allergy and Immunology 2006; Vol. 31, issue 2-3:181-96.

\section{Harvey 1982}

Harvey JE, Tattersfield AE. Airway response to salbutamol effect of regular salbutamol inhalations in normal, atopic, and asthmatic subjects. Thorax 1982; Vol. 37, issue 4: 280-7.

\section{Jaeschke 2008}

Jaeschke R, O'Byrne PM, Nair P, Mejza F, Lesniak W, Brozek J, et al.The safety of formoterol among patients with asthma using inhaled corticosteroids. Systematic review and meta-analysis. Polskie Archiwum Medycyny Wewnetrznej 2008; Vol. 118, issue 11:627-35.

\section{Jaeschke 2008a}

Jaeschke R, O’Byrne PM, Mejza F, Nair P, Lesniak W, Brozek J, et al.The safety of long-acting beta-agonists among patients with asthma using inhaled corticosteroids: systematic review and meta-analysis. American Journal of Respiratory and Critical Care Medicine 2008; Vol. 178, issue 10:1009-16.

\section{Jones 2001}

Jones SL, Cowan JO, Flannery EM, Hancox RJ, Herbison GP, Taylor DR. Reversing acute bronchoconstriction in asthma: the effect of bronchodilator tolerance after treatment with formoterol. European Respiratory Journal 2001; Vol. 17, issue 3:368-73.

Lee 2003

Lee DKC, Jackson CM, Currie GP, Cockburn WJ, Lipworth BJ. Comparison of combination inhalers vs inhaled corticosteroids alone in moderate persistent asthma. British Journal of Clinical Pharmacology 2003; Vol. 56, issue 5:494-500.

\section{Lipworth 1989}

Lipworth BJ, Struthers AD, McDevitt DG. Tachyphylaxis to systemic but not to airway responses during prolonged therapy with high-dose inhaled salbutamol in asthmatics. American Review of Respiratory Disease 1989; Vol. 140, issue 3:586-92.

\section{Lipworth 1992}

Lipworth BJ, McDevitt DG. Inhaled beta-2-adrenoceptor agonists in asthma - help or hindrance. British Journal of Clinical Pharmacology 1992; Vol. 33, issue 2:129-38.

\section{Lipworth 1997}

Lipworth BJ. Airway subsensitivity with long-acting beta 2agonists: is there cause for concern?. Drug Safety 1997;16 (5):295-308

\section{Lipworth 2000}

Lipworth BJ, Aziz I. Bronchodilator response to albuterol after regular formoterol and effects of acute corticosteroid administration. Chest 2000; Vol. 117, issue 1:156-62.

McDevitt 1974

McDevitt DG, Shanks RG, Swanton JG. Further observations on cardiotoxicity of isoprenaline during hypoxia. British Journal of Pharmacology 1974; Vol. 50, issue 3:335-44.

\section{McIvor 1998}

McIvor RA, Pizzichini E, Turner MO, Hussack P, Hargreave FE, Sears MR. Potential masking effects of salmeterol on airway inflammation in asthma. American Journal of Respiratory and Critical Care Medicine 1998; Vol. 158, issue 3:924-30.

\section{Morrison 1993}

Morrison KJ, Gao Y, Vanhoutte PM. Beta-adrenoceptors and the epithelial layer in airways. Life Sciences 1993; Vol. 52, issue 26:2123-30.

Nelson 1977

Nelson HS, Raine D, Doner HC, Posey WC. Subsensitivity to bronchodilator action of albuterol produced by chronic administration. American Review of Respiratory Disease 1977; Vol. 116, issue 5:871-8.

\section{Ni Chroinin 2005}

$\mathrm{Ni}$ Chroinin M, Greenstone IR, Danish A, Magdolinos $\mathrm{H}$, Masse $\mathrm{V}$, Zhang $\mathrm{X}$, et al.Long-acting beta2-agonists versus placebo in addition to inhaled corticosteroids in children and adults with chronic asthma. Cochrane Database of Systematic Reviews 2005, Issue 4. [DOI: 10.1002/ 14651858.CD005535]

Ni Chroinin 2009

$\mathrm{Ni}$ Chroinin M, Greenstone IR, Ducharme FM. Addition of long-acting beta2-agonists to inhaled steroids as first line therapy for persistent asthma in steroid-naive adults and children. Cochrane Database of Systematic Reviews 2010, Issue 2. [DOI: 10.1002/14651858.CD005307]

\section{Palmqvist 1999}

Palmqvist M, Ibsen T, Mellen A, Lotvall J. Comparison of the relative efficacy of formoterol and salmeterol in asthmatic patients. American Journal of Respiratory and Critical Care Medicine 1999; Vol. 160, issue 1:244-9.

\section{Pearce 1990}

Pearce N, Grainger J, Atkinson M, Crane J, Burgess C, Culling C, et al.Case-control study of prescribed fenoterol and death from asthma in New Zealand, 1977-81. Thorax 1990; Vol. 45, issue 3:170-5.

\section{Pearce 2007}

Pearce N. Adverse Reactions: the Fenoterol Story. 1. Auckland: Auckland University Press, 2007:215. [ISBN: 9781869403744]

\section{RevMan 2011}

The Nordic Cochrane Centre, The Cochrane Collaboration. Review Manager (RevMan). 5.1. Copenhagen: The Nordic Cochrane Centre, The Cochrane Collaboration, 2011.

\section{Salpeter 2006}

Salpeter SR, Buckley NS, Ormiston TM, Salpeter EE. Meta-analysis: effect of long-acting beta-agonists on severe asthma exacerbations and asthma-related deaths. Annals of Internal Medicine 2006;144(12):904-12.

\section{Sears 1986}

Sears M, Rea H, Rothwell R, O’Donnell T, Holst P, Gillies A, et al.Asthma mortality: comparison between New 
Zealand and England. British Medical Journal 1986;293 (6558):1342-5.

\section{Sears 1990}

Sears MR, Taylor DR, Print CG, Lake DC, Li QQ,

Flannery EM, et al.Regular inhaled beta-agonist treatment in bronchial-asthma. Lancet 1990; Vol. 336, issue 8728: 1391-6.

\section{SMART 2006}

Nelson HS, Weiss ST, Bleecker ER, Yancey SW, Dorinsky PM, the SMART Study Group. The Salmeterol Multicenter Asthma Research Trial: a comparison of usual pharmacotherapy for asthma or usual pharmacotherapy plus salmeterol. Chest 2006;129:15-26.

\section{Speizer 1968}

Speizer FE, Doll R, Heaf P. Observations on recent increase in mortality from asthma. British Medical Journal 1968; Vol. 1, issue 5588:335-7.

van der Woude 2001

van der Woude HJ, Winter TH, Aalbers R.

Decreased bronchodilating effect of salbutamol in relieving methacholine induced moderate to severe bronchoconstriction during high dose treatment with long acting beta(2) agonists. Thorax 2001; Vol. 56, issue 7: 529-35.

\section{van Noord 1996}

van Noord JA, Smeets JJ, Raaijmakers JAM, Bommer AM, Maesen FPV. Salmeterol versus formoterol in patients with moderately severe asthma: onset and duration of action. European Respiratory Journal 1996; Vol. 9, issue 8:1684-8.

\section{Walters 2002}

Walters EH, Walters JAE, Gibson PW. Regular treatment with long acting beta agonists versus daily regular treatment with short acting beta agonists in adults and children with stable asthma. Cochrane Database of Systematic Reviews 2009, Issue 1. [DOI: 10.1002/14651858.CD003901]

Walters 2007

Walters EH, Gibson PG, Lasserson TJ, Walters JAE. Long-acting beta2-agonists for chronic asthma in adults and children where background therapy contains varied or no inhaled corticosteroid. Cochrane Database of Systematic Reviews 2008, Issue 4. [DOI: 10.1002/ 14651858.CD001385.pub2]

\section{Weber 1982}

Weber RW, Smith JA, Nelson HS. Aerosolized terbutaline in asthmatics - development of subsensitivity with longterm administration. Journal of Allergy and Clinical Immunology 1982; Vol. 70, issue 6:417-22.

\section{Wilson 1981}

Wilson JD, Sutherland DC, Thomas AC. Has the change to beta-agonists combined with oral theophylline increased cases of fatal asthma. Lancet 1981; Vol. 1, issue 8232: $1235-7$.

\section{Wong 1990}

Wong CS, Pavord ID, Williams J, Britton JR, Tattersfield AE. Bronchodilator, cardiovascular, and hypokalemic effects of fenoterol, salbutamol, and terbutaline in asthma. Lancet 1990; Vol. 336, issue 8728:1396-9.

\section{Yates 1996}

Yates DH, Kharitonov SA, Barnes PJ. An inhaled glucocorticoid does not prevent tolerance to the bronchoprotective effect of a long-acting inhaled beta(2)agonist. American Journal of Respiratory and Critical Care Medicine 1996; Vol. 154, issue 6:1603-7.

* Indicates the major publication for the study 
CHARACTERISTICS OF STUDIES

Characteristics of included studies [ordered by study ID]

Condemi 2001

Methods

Study design: a randomised, open-label, multicentre, parallel-group study over 6 months from September 1998 to June 1999 at 100 centres. Run-in: 1 week, long-acting beta 2 agonists appear to have been withdrawn.

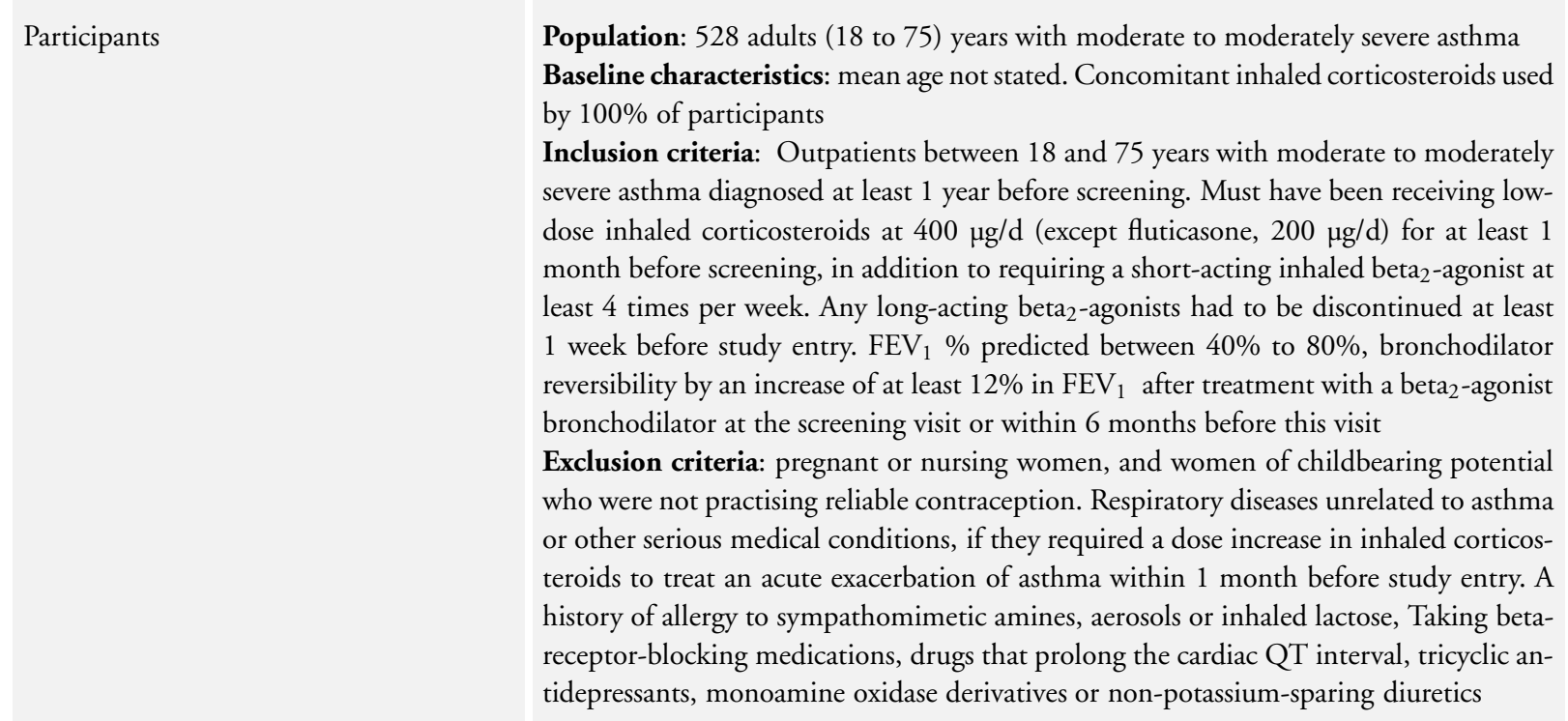

Interventions 1. Formoterol $12 \mu \mathrm{g}$ BD (Foradil Aerolizer)

2. Salmeterol $50 \mu \mathrm{g}$ BD (Serevent Diskus inhaler)

Delivery was DPI

Outcomes

The primary end point was mean morning PEF measure 5 minutes after dosing. SAEs reported (all-cause and asthma-related)

"No deaths were reported in either treatment arm. SAEs were reported in 7 patients receiving formoterol (1 each, bronchospasm, chest pain, cholelithiasis, colon cancer, dyspnea, fracture, syncope) and 12 patients receiving salmeterol (1 each, abdominal pain, amnesia, appendicitis, bronchitis, cranial injury, fracture, glioma, intervertebral disc disorder, metastases, myocardial infarction; 2, breast cancer). In addition, asthma was reported as a serious adverse event in 2 patients receiving formoterol and 3 patients receiving salmeterol."

Notes Sponsored by Novartis

Risk of bias

Bias

Authors' judgement

Support for judgement

Regular treatment with formoterol versus regular treatment with salmeterol for chronic asthma: serious adverse events (Review) 
Condemi 2001 (Continued)

\begin{tabular}{|c|c|c|}
\hline $\begin{array}{l}\text { Random sequence generation (selection } \\
\text { bias) }\end{array}$ & Unclear risk & No details of randomisation process \\
\hline Allocation concealment (selection bias) & Unclear risk & No details of randomisation process \\
\hline $\begin{array}{l}\text { Blinding (performance bias and detection } \\
\text { bias) } \\
\text { All outcomes }\end{array}$ & High risk & Open study \\
\hline $\begin{array}{l}\text { Incomplete outcome data (attrition bias) } \\
\text { All outcomes }\end{array}$ & Low risk & $\begin{array}{l}85.5 \% \text { on formoterol and } 88.7 \% \text { on salme- } \\
\text { terol completed the study }\end{array}$ \\
\hline Selective reporting (reporting bias) & Low risk & SAE results reported in the paper \\
\hline
\end{tabular}

Everden 2004

\begin{tabular}{ll} 
Methods & $\begin{array}{l}\text { Study design: an open randomised, double-blind, parallel-group study over } 12 \text { weeks } \\
\text { at } 58 \text { general practice centres (UK (56), Republic of Ireland(2)). Run-in } 7 \text { to } 10 \text { days }\end{array}$ \\
\hline Participants & $\begin{array}{l}\text { Population: } 156 \text { children ( } 6 \text { to } 17 \text { ) years with moderate persistent asthma } \\
\text { Baseline characteristics: mean age } 12 \text { years. Concomitant inhaled corticosteroids used } \\
\text { by } 100 \% \text { of participants. PEF at randomisation } 317.5 \pm 110.4 \text { (eformoterol) } 311.5 \pm \\
109.2 \text { (salmeterol). } \\
\text { Inclusion criteria: outpatients aged } 6 \text { to } 17 \text { years, with a clinical diagnosis of moderate, } \\
\text { persistent asthma. Had to have been receiving ICS for asthma at a constant dose for } \\
\text { at least } 4 \text { weeks prior to enrolment, currently using inhaled short-acting beta } 2 \text {-agonists } \\
\text { for relief of asthma symptoms, and have had asthma symptoms occurring on at least } 3 \\
\text { days or nights out of the past } 7 \text { days prior to enrolment. For randomisation, needed to } \\
\text { have continued to experience asthma symptoms and to have used at least } 7 \text { actuations } \\
\text { of short-acting b2-agonists in the last } 7 \text { days or nights for relief of asthma symptoms } \\
\text { Exclusion criteria: PEF predicted less than } 50 \% \text {, asthma symptoms requiring imme- } \\
\text { diate treatment, significant concurrent disease or health problems, or a requirement for } \\
\text { additional medication (e.g. B-blocker therapy, nebulised therapy, oral steroids or oral } \\
\text { short-acting beta } 2 \text {-agonists) which may have interfered with the evaluation of the study } \\
\text { drug }\end{array}$ \\
\hline
\end{tabular}

\begin{tabular}{l|l}
\hline Interventions & 1. Formoterol $12 \mu \mathrm{g}$ bid (Oxis Turbohaler, delivered dose $9 \mu \mathrm{g})$ \\
2. Salmeterol $50 \mu \mathrm{g}$ bid (Accuhaler) \\
Delivery was DPI
\end{tabular}

Outcomes

Primary outcome variable was the comparison of treatments via diary card assessment of changes in daytime short-acting b2-agonist use during the 7 days prior to the final (week 12) clinic visit. SAEs reported

"Two patients reported serious AEs, testicular torsion (eformoterol) and diabetes mellitus (salmeterol), but neither were considered related to test treatment." 
Everden 2004 (Continued)

\begin{tabular}{|c|c|c|}
\hline Bias & Authors' judgement & Support for judgement \\
\hline $\begin{array}{l}\text { Random sequence generation (selection } \\
\text { bias) }\end{array}$ & Low risk & $\begin{array}{l}\text { Computer-generated randomisation } \\
\text { scheme }\end{array}$ \\
\hline Allocation concealment (selection bias) & Unclear risk & No details \\
\hline $\begin{array}{l}\text { Blinding (performance bias and detection } \\
\text { bias) } \\
\text { All outcomes }\end{array}$ & High risk & Open \\
\hline $\begin{array}{l}\text { Incomplete outcome data (attrition bias) } \\
\text { All outcomes }\end{array}$ & Low risk & $\begin{array}{l}33 \text { patients discontinued the study (for- } \\
\text { moterol } 21 \text {, salmeterol } 12 \text { ). All patients } \\
\text { who took at least } 1 \text { dose of medication were } \\
\text { included in the analysis }\end{array}$ \\
\hline Selective reporting (reporting bias) & Low risk & SAE data reported \\
\hline
\end{tabular}

\section{Gabbay 1998}

Methods

Participants
Study design: 3 -month, randomised, open, parallel-group, multicentre $(55$ centres) general practice-based study. 2-week run-in period. From October 1995 to December 1996

Population: 127 participants with asthma on regular maintenance anti-inflammatory therapy, but still complained of night time symptoms

Baseline characteristics: mean age not stated. Concomitant inhaled corticosteroids used by $100 \%$ of participants

Inclusion criteria: patients had to be at least 18 years or age with reversible obstructive airways disease, with significant nocturnal symptoms at least twice per week and PEF $50 \%$ to $80 \%$ previous best at least 3 times per week during run-in. Concomitant inhaled corticosteroids: all patients were on a stable dose of at least $400 \mu \mathrm{g}$ BDP daily (or equivalent)

Exclusion criteria: no details

Interventions

1. Formoterol $12 \mu \mathrm{g}$ BD (Foradil Aerolizer)

2. Salmeterol $50 \mu \mathrm{g}$ BD (Serevent Diskus inhaler)

Delivery was DPI

Outcomes

Day and night symptoms, morning and evening pre-drug PEF, rescue medication use. No information on adverse events found in abstract

Novartis have provided data on file indicating that there were no deaths in this study. There was only 1 patient in the salmeterol group who suffered a SAE (asthma exacerbation). This was not included in the safety analysis as there was no confirmation that the patient had taken any study medication 
Gabbay 1998 (Continued)

\begin{tabular}{l|ll}
\hline Notes & Sponsored by Novartis & \\
\hline Risk of bias & Authors' judgement & Support for judgement \\
\hline Bias & Unclear risk & No details \\
\hline $\begin{array}{l}\text { Random sequence generation (selection } \\
\text { bias) }\end{array}$ & Unclear risk & No details \\
\hline $\begin{array}{l}\text { Allocation concealment (selection bias) } \\
\text { Blinding (performance bias and detection } \\
\text { bias) } \\
\text { All outcomes }\end{array}$ & High risk & Open \\
\hline $\begin{array}{l}\text { Incomplete outcome data (attrition bias) } \\
\text { All outcomes }\end{array}$ & Unclear risk & 106 of 127 randomised were analysed for \\
\hline \begin{tabular}{l} 
Selective reporting (reporting bias) \\
\hline
\end{tabular} & Low risk & safety \\
\hline
\end{tabular}

\section{Vervloet 1998}

\begin{tabular}{|c|c|}
\hline Methods & $\begin{array}{l}\text { Study design: a randomised, open, multicentre, parallel-group study over } 6 \text { months } \\
\text { at } 41 \text { centres (France, Italy, Spain, Sweden, Switzerland, United Kingdom). Run-in } 2 \\
\text { weeks }\end{array}$ \\
\hline Participants & $\begin{array}{l}\text { Population: } 482 \text { adults ( } 18 \text { to } 78 \text { ) years with moderate to severe asthma } \\
\text { Baseline characteristics: mean age } 48 \text { years. Morning PEF } 374 \text {, evening PEF } 386 \text {. } \\
\text { Concomitant inhaled corticosteroids used by } 100 \% \text { of participants } \\
\text { Inclusion criteria: outpatients with a documented diagnosis of reversible obstructive } \\
\text { airways disease for } 1 \text { year or more, using regular inhaled corticosteroids at a constant } \\
\text { dose of at least } 400 \mu \mathrm{g} \text { day (or } 200 \mu \mathrm{g} \text { day fluticasone) for at least } 1 \text { month before } \\
\text { inclusion. No attempt was made to exclude reversible COPD but the authors state that } \\
\text { the vast majority of participants would have had asthma based on the inclusion criteria } \\
\text { Exclusion criteria: evidence of other clinically relevant diseases, pregnant or lactating } \\
\text { women, patients on beta-blocker therapy or with hypersensitivity to sympathomimetic } \\
\text { amines or inhaled lactose }\end{array}$ \\
\hline Interventions & $\begin{array}{l}\text { 1. Formoterol } 12 \mu \mathrm{g} \text { BD (Foradil Aerolizer) } \\
\text { 2. Salmeterol } 50 \mu \mathrm{g} \mathrm{BD} \text { (Serevent Diskus inhaler) } \\
\text { Delivery was DPI }\end{array}$ \\
\hline Outcomes & $\begin{array}{l}\text { Outcome: the primary efficacy variable was the mean morning pre-dose PEF during the } \\
\text { last } 7 \text { days of treatment } \\
\text { No reported data on SAEs or mortality in the paper but data on file obtained from } \\
\text { Novartis. } 1 \text { death occurred in the salmeterol group following myocardial infarction. } 19 \\
\text { patients suffered a serious adverse event on formoterol and } 22 \text { on salmeterol (including } \\
\text { the } 1 \text { patient who died); } 4 \text { patients on formoterol and } 4 \text { on salmeterol suffered an }\end{array}$ \\
\hline
\end{tabular}


asthma-related serious adverse event, and 1 additional patient on formoterol developed respiratory failure

\begin{tabular}{ll}
\hline Notes & Sponsored by Novartis \\
\hline
\end{tabular}

\section{Risk of bias}

\begin{tabular}{l|l|l}
\hline Bias & Authors' judgement & Support for judgement \\
\hline $\begin{array}{l}\text { Random sequence generation (selection } \\
\text { bias) }\end{array}$ & Low risk & $\begin{array}{l}\text { Computer- } \\
\text { generated randomisation scheme was used } \\
\text { to provide balanced blocks of patient num- } \\
\text { bers for the 2 treatment groups within each } \\
\text { country. A one-to-one treatment allocation } \\
\text { and a block size of } 8 \text { were used }\end{array}$ \\
\hline Allocation concealment (selection bias) & Unclear risk & No details \\
\hline $\begin{array}{l}\text { Blinding (performance bias and detection } \\
\text { bias) } \\
\text { All outcomes }\end{array}$ & High risk & Open \\
\hline $\begin{array}{l}\text { Incomplete outcome data (attrition bias) } \\
\text { All outcomes }\end{array}$ & Low risk & 428/482 (89\%) completed the study \\
\hline \begin{tabular}{l} 
Selective reporting (reporting bias) \\
\hline
\end{tabular} & Low risk & Full SAE data obtained from Novartis \\
\hline
\end{tabular}

AE: adverse event; BD: twice a day; COPD: chronic obstructive pulmonary disease; BDP: budesonide diphosphionate; DPI: dry powder inhaler; $\mathrm{FEV}_{1}$ : forced expiratory volume in one second; ICS: inhaled corticosteroids; PEF: peak expiratory flow; SAE: serious adverse event

\section{Characteristics of excluded studies [ordered by study ID]}

\begin{tabular}{l|l}
\hline Study & Reason for exclusion \\
\hline Brambilla 2003 & 4-week study \\
\hline Campbell 1999 & 8-week study, followed by 4-week cross-over to assess patient preference \\
\hline Eryonucu 2005 & Single-dose study \\
\hline Heijerman 1999 & 6-week study \\
\hline Larsson 1990 & Review of 3 other studies
\end{tabular}


(Continued)

\begin{tabular}{ll}
\hline Lemaigre 2006 & Single-dose study \\
\hline Novartis 2005 & Comparison between different ways of using formoterol (no salmeterol arm) \\
\hline Pohunek 2004 & Single-dose cross-over study \\
\hline Sill 1999 & Single-dose study \\
\hline van der Woude 2004 & Single-dose study \\
\hline van Veen 2003 & Cross-over study of bronchodilator tolerance \\
\hline Verini 1998 & 5-day treatment periods \\
\hline Von Berg 2003 & No salmeterol arm \\
\hline
\end{tabular}


DATA AND ANALYSES

Comparison 1. Regular formoterol versus regular salmeterol

\begin{tabular}{|c|c|c|c|c|}
\hline Outcome or subgroup title & $\begin{array}{l}\text { No. of } \\
\text { studies }\end{array}$ & $\begin{array}{c}\text { No. of } \\
\text { participants }\end{array}$ & Statistical method & Effect size \\
\hline 1 All-cause mortality & 4 & 1272 & Risk Difference (M-H, Fixed, 95\% CI) & $-0.00[-0.01,0.01]$ \\
\hline 1.1 Adults & 3 & 1116 & Risk Difference (M-H, Fixed, 95\% CI) & $-0.00[-0.01,0.01]$ \\
\hline 1.2 Children & 1 & 156 & Risk Difference (M-H, Fixed, 95\% CI) & $0.0[-0.02,0.02]$ \\
\hline 2 All-cause SAEs & 4 & 1272 & Peto Odds Ratio (Peto, Fixed, 95\% CI) & $0.77[0.47,1.28]$ \\
\hline 2.1 Adults & 3 & 1116 & Peto Odds Ratio (Peto, Fixed, 95\% CI) & $0.77[0.46,1.28]$ \\
\hline 2.2 Children & 1 & 156 & Peto Odds Ratio (Peto, Fixed, 95\% CI) & $0.95[0.06,15.33]$ \\
\hline 3 Asthma-related SAEs & 4 & 1272 & Peto Odds Ratio (Peto, Fixed, 95\% CI) & $0.86[0.29,2.57]$ \\
\hline 3.1 Adults & 3 & 1116 & Peto Odds Ratio (Peto, Fixed, 95\% CI) & $0.86[0.29,2.57]$ \\
\hline 3.2 Children & 1 & 156 & Peto Odds Ratio (Peto, Fixed, 95\% CI) & $0.0[0.0,0.0]$ \\
\hline $\begin{array}{l}4 \text { All-cause SAEs (Sensitivity } \\
\text { analysis) }\end{array}$ & 4 & 1272 & Peto Odds Ratio (Peto, Fixed, 95\% CI) & $0.75[0.46,1.24]$ \\
\hline 4.1 Adults & 3 & 1116 & Peto Odds Ratio (Peto, Fixed, 95\% CI) & $0.75[0.45,1.24]$ \\
\hline 4.2 Children & 1 & 156 & Peto Odds Ratio (Peto, Fixed, 95\% CI) & $0.95[0.06,15.33]$ \\
\hline $\begin{array}{l}5 \text { Asthma-related SAEs (Sensitivity } \\
\text { analysis) }\end{array}$ & 4 & 1272 & Peto Odds Ratio (Peto, Fixed, 95\% CI) & $0.76[0.26,2.17]$ \\
\hline 5.1 Adults & 3 & 1116 & Peto Odds Ratio (Peto, Fixed, 95\% CI) & $0.76[0.26,2.17]$ \\
\hline 5.2 Children & 1 & 156 & Peto Odds Ratio (Peto, Fixed, 95\% CI) & $0.0[0.0,0.0]$ \\
\hline
\end{tabular}




\section{Analysis I.I. Comparison I Regular formoterol versus regular salmeterol, Outcome I All-cause mortality.}

Review: Regular treatment with formoterol versus regular treatment with salmeterol for chronic asthma: serious adverse events

Comparison: I Regular formoterol versus regular salmeterol

Outcome: I All-cause mortality

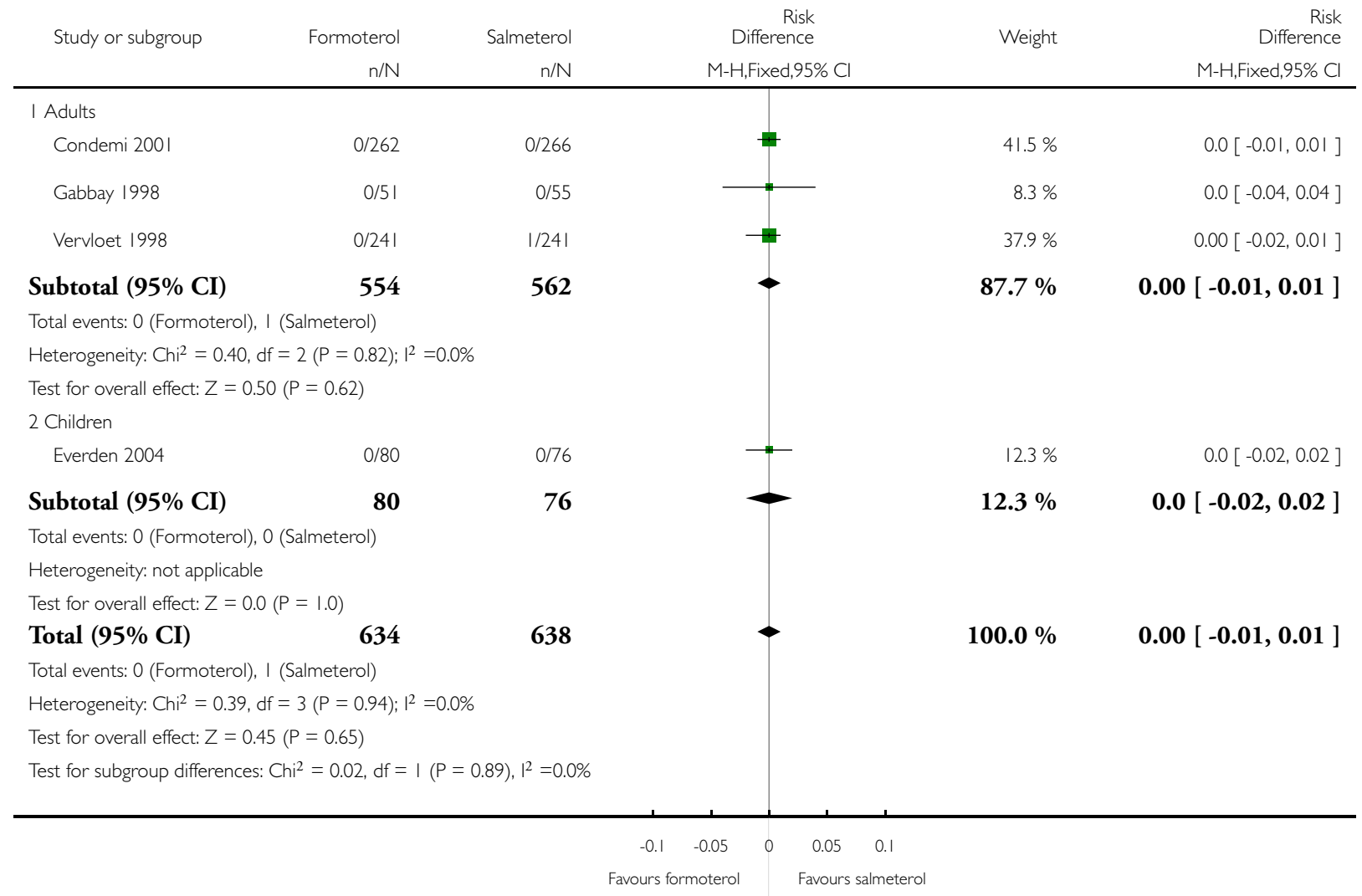


Analysis I.2. Comparison I Regular formoterol versus regular salmeterol, Outcome 2 All-cause SAEs.

Review: Regular treatment with formoterol versus regular treatment with salmeterol for chronic asthma: serious adverse events

Comparison: I Regular formoterol versus regular salmeterol

Outcome: 2 All-cause SAEs

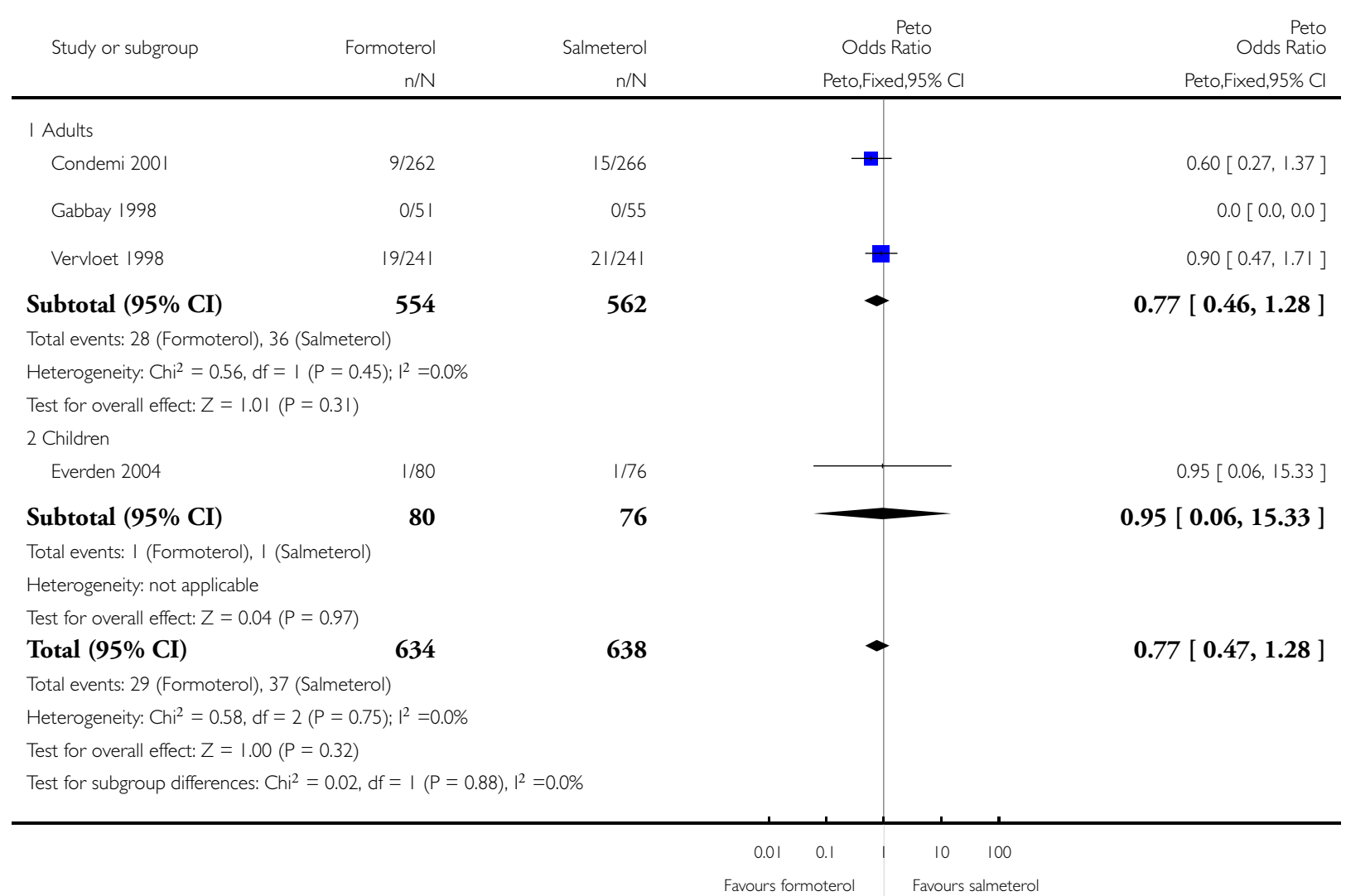


Analysis I.3. Comparison I Regular formoterol versus regular salmeterol, Outcome 3 Asthma-related SAEs.

Review: Regular treatment with formoterol versus regular treatment with salmeterol for chronic asthma: serious adverse events

Comparison: I Regular formoterol versus regular salmeterol

Outcome: 3 Asthma-related SAEs

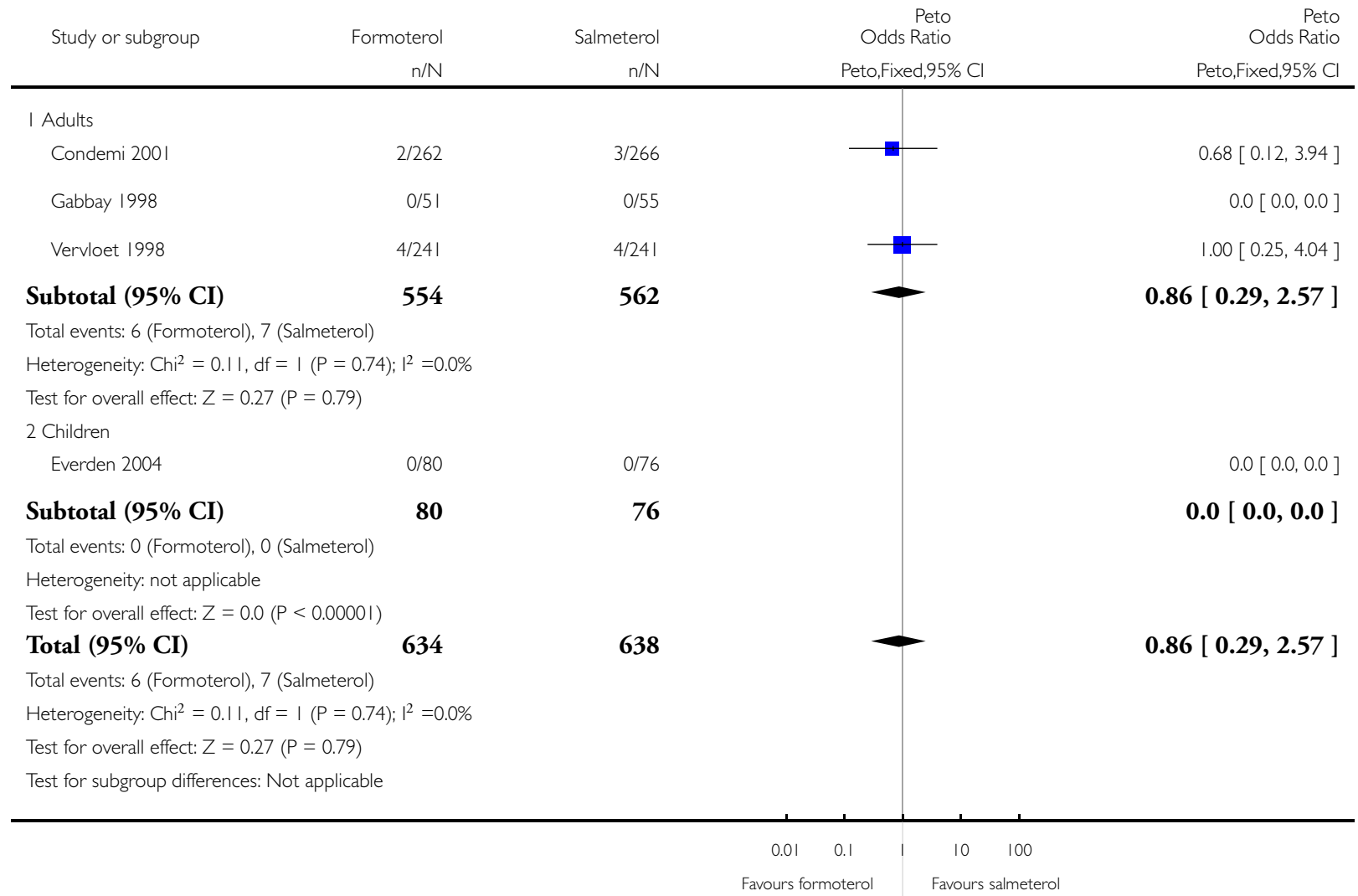


Analysis 1.4. Comparison I Regular formoterol versus regular salmeterol, Outcome 4 All-cause SAEs (Sensitivity analysis).

Review: Regular treatment with formoterol versus regular treatment with salmeterol for chronic asthma: serious adverse events

Comparison: | Regular formoterol versus regular salmeterol

Outcome: 4 All-cause SAEs (Sensitivity analysis)

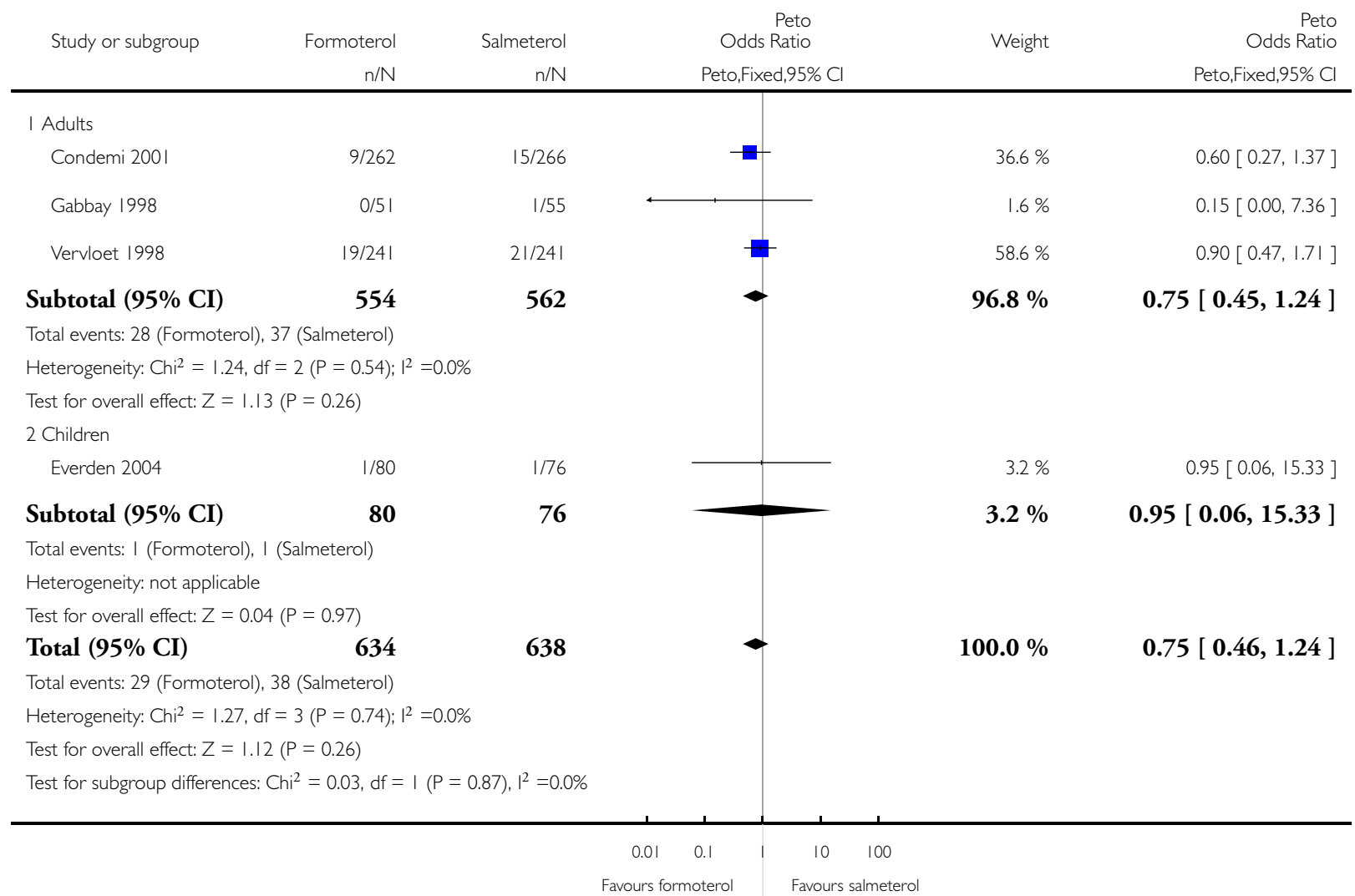


Analysis I.5. Comparison I Regular formoterol versus regular salmeterol, Outcome 5 Asthma-related SAEs (Sensitivity analysis).

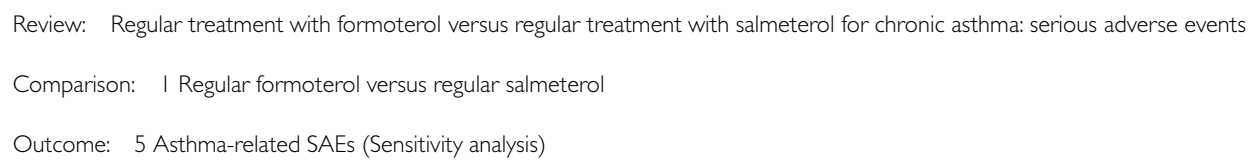

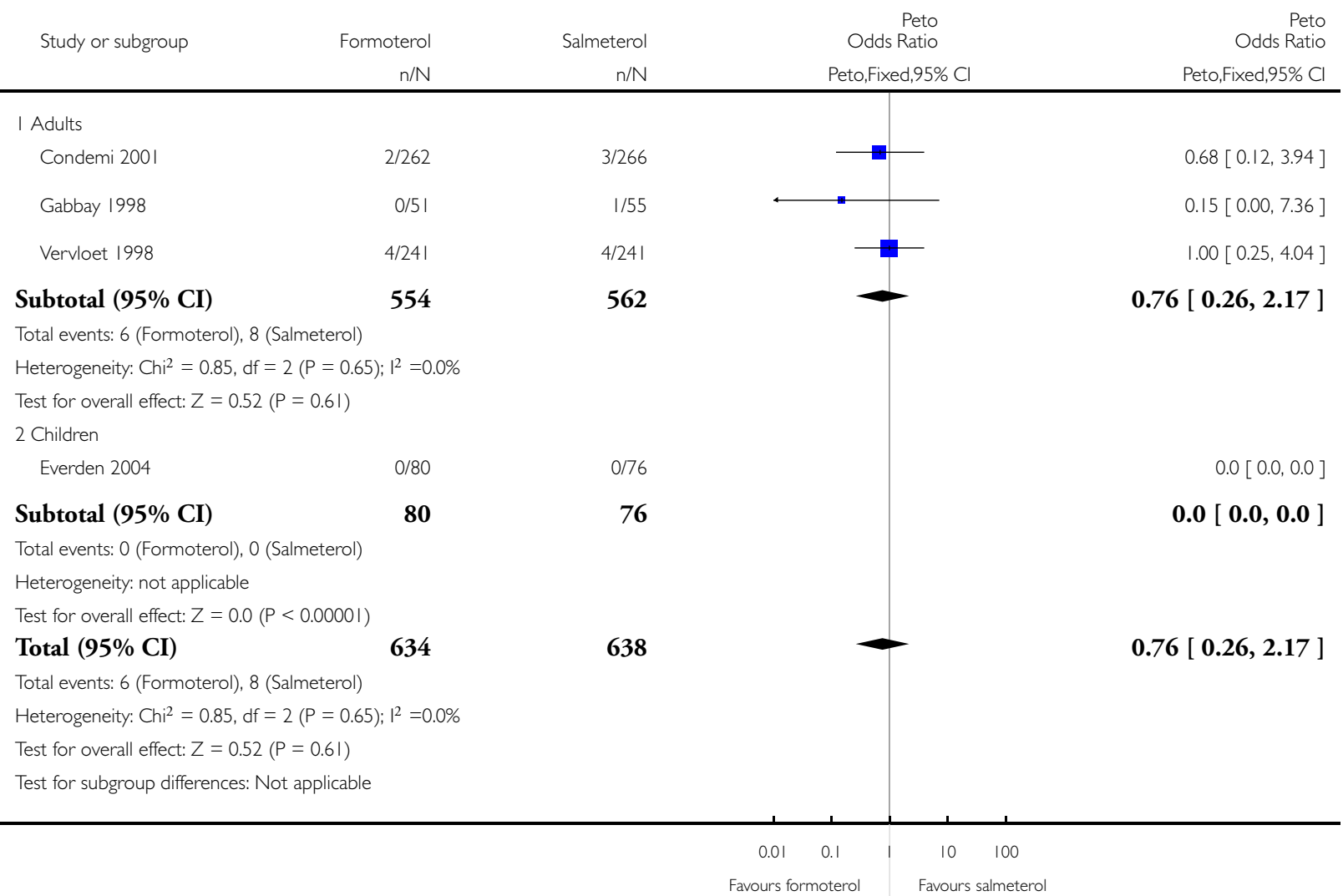

\section{ADDITIONAL TABLES}

Table 1. Intrinsic efficacy of beta-agonists

\begin{tabular}{ll}
\hline Drug & Intrinsic efficacy (\%) \\
\hline Isoprenaline, adrenaline & 100 \\
\hline Fenoterol & 42 \\
\hline Formoterol & 20 \\
\hline Salbutamol & 4.9 \\
\hline
\end{tabular}

Regular treatment with formoterol versus regular treatment with salmeterol for chronic asthma: serious adverse events (Review) 
Table 1. Intrinsic efficacy of beta-agonists (Continued)

Salmeterol
$\begin{aligned} & \text { Adapted from Hanania 2002. The authors acknowledge that it is difficult to determine the intrinsic efficacy of salmeterol given its high } \\ & \text { lipophilicity. }\end{aligned}$

apted from Hanania 2002. The authors acknowledge that it is difficult to determine the intrinsic efficacy of salmeterol given its high

\section{A P PEN D I CES}

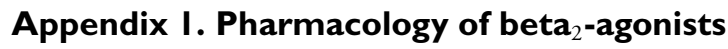

Beta 2 -agonists are thought to cause bronchodilation primarily through binding beta 2 -adrenoceptors on airways smooth muscle (ASM), with subsequent activation of both membrane-bound potassium channels and a signalling cascade involving enzyme activation and changes in intracellular calcium levels following a rise in cyclic adenosine monophosphate (cAMP) (Barnes 1993). However, beta2adrenoceptors are also expressed on a wide range of cell types where beta 2 -agonists may have a clinically significant effect including airway epithelium (Morrison 1993), mast cells, post capillary venules, sensory and cholinergic nerves and dendritic cells (Anderson

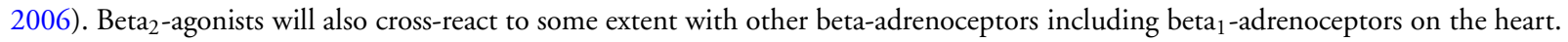
The in vivo effect of any beta 2 -agonist will depend on a number of factors relating to both the drug and the patient. The degree to which a drug binds to one receptor over another is known as selectivity, which can be defined as absolute binding ratios to different receptors in vitro, whilst functional selectivity is measured from downstream effects of drugs in different tissue types in vitro or in vivo. All of the beta ${ }_{2}$-agonists described thus far are more beta 2 selective than their predecessor isoprenaline in vitro. However, because attempts to differentiate selectivity between the newer agents are confounded by so many factors, it is difficult to draw conclusions about in vitro selectivity studies and probably best to concentrate on specific adverse side effects in human subjects at doses which cause the same degree of bronchoconstriction. The potency of a drug refers to the concentration that achieves half the maximal receptor activation of which that drug is capable but it is not very important clinically as for each drug, manufacturers will alter the dose to try to achieve a therapeutic ratio of desired to undesired effects. In contrast efficacy refers to the ability of a drug to activate its receptor independent of drug concentration. Drugs that fully activate a receptor are known as full agonists and those that partially activate a receptor are known as partial agonists. Efficacy also is very much dependent on the system in which it is being tested and is affected by factors including the number of receptors available and the presence of other agonists and antagonists. Thus whilst salmeterol acts as a partial agonist in vitro it causes a similar degree of bronchodilation to the strong agonist formoterol in stable asthmatic patients (van Noord 1996), presumably because there are an abundance of well-coupled beta2-adrenoceptors available with few downstream antagonising signals. In contrast, with repetitive dosing formoterol is significantly better than salmeterol at preventing methacholineinduced bronchoconstriction (Palmqvist 1999). These differences have led to attempts to define the "intrinsic efficacy" of a drug independent of tissue conditions (Hanania 2002), as shown in Table 1. The clinical significance of intrinsic efficacy remains unclear.

\section{Appendix 2. Possible mechanisms of increased asthma mortality with beta-agonists}

\section{Direct toxicity}

This hypothesis states that direct adverse effects of beta 2 -agonists are responsible for an associated increase in mortality and most research in the area has concentrated on effects detrimental to the heart. Whilst it is often assumed that cardiac side effects of beta 2 -agonists

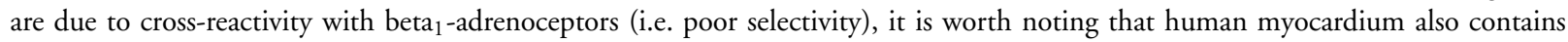

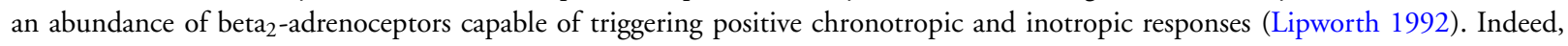
there is good evidence that cardiovascular side effects of isoprenaline (Arnold 1985) and other beta 2 -agonists including salbutamol (Hall 1989) are mediated predominantly via cardiac beta 2 -adrenoceptors thus making the concept of in vitro selectivity less relevant. 
Generalised beta 2 -adrenoceptor activation can also cause hypokalaemia (Brown 1983) and it has been proposed that, through these and other actions beta 2 -agonists may predispose to life-threatening dysrhythmias or cause other adverse cardiac effects.

During the 1960s epidemic most deaths occurred in patients with severe asthma and it was originally assumed that asthma and its sequelae, including hypoxia, were the primary cause of death. However, mucus plugging and hypoxia does not preclude a cardiac event as the final cause of death, and one might expect those with severe asthma to take more doses of a prescribed inhaler. As noted by Speizer and Doll most deaths in the 1960s were in the 10 to 19 age group and "at these ages children have begun to act independently and may be particularly prone to misuse a self-administered form of treatment" (Speizer 1968). If toxicity were related to increasing doses of beta 2 -agonists one might expect most deaths to occur in hospital where high doses are typically used and this was not the case. One possible explanation for this anomaly was provided by animal experiments in which large doses of isoprenaline caused little ill effect in anaesthetised dogs with normal arterial oxygenation whereas much smaller doses caused fatal cardiac depression and asystole (although no obvious dysrhythmia) when hypoxic (Collins 1969; McDevitt 1974). It has been hypothesised therefore that such events would be less likely in hospital where supplemental oxygen is routinely given. The clinical relevance of these studies remains unclear although there is some evidence of a synergistic effect between hypoxia and salbutamol use in asthmatic patients in reducing total peripheral vascular resistance (Burggraaf 2001) - another beta 2 mediated effect which could be detrimental to the heart during an acute asthma attack through a reduction in diastolic blood pressure. Other potential mechanisms of isoprenaline toxicity include a potential increase in mucous plugging and worsening of ventilation perfusion mismatch despite bronchodilation (Pearce 1990).

Further concerns about a possible toxic effect of beta 2 -agonists were raised during the New Zealand epidemic in the 1970s. In 1981 Wilson et al, who first reported the epidemic, reviewed 22 fatal cases of asthma and noted "In 16 patients death was seen to be sudden and unexpected. Although all were experiencing respiratory distress, most were not cyanosed and the precipitate nature of their death suggested a cardiac event, such as an arrest, inappropriate to the severity of their respiratory problem" (Wilson 1981). In humans, fenoterol causes significantly greater chronotropic, inotropic and electrocardiographic side effects than salbutamol in asthmatic patients (Wong 1990). Interestingly, across the same parameters fenoterol also causes more side effects than isoprenaline (Burgess 1991).

In patients with mild asthma and without a bronchoconstrictor challenge, salmeterol and salbutamol cause a similar degree of near maximal bronchodilation at low doses (Bennett 1994). However, whilst as a one-off dose salbutamol is typically used at two to four times the concentration of salmeterol, the dose equivalences for salmeterol versus salbutamol in increasing heart rate and decreasing potassium concentration and diastolic blood pressure were 17.7, 7.8 and 7.6 respectively (i.e. salmeterol had a greater effect across all parameters). Given the lower intrinsic efficacy of salmeterol (Table 1), these results highlight the importance of in vivo factors; one possible explanation for the difference is the increased lipophilicity of salmeterol compared to salbutamol contributing to higher systemic absorption (Bennett 1994).

When comparing increasing actuations of standard doses of formoterol and salmeterol inhalers in stable asthmatic patients, relatively similar cardiovascular effects are seen at lower doses (Guhan 2000). However, at the highest doses (above those recommended by the manufacturers) there were trends towards an increase in systolic blood pressure with formoterol; in comparison there was a trend towards a decrease in diastolic blood pressure and an increase in QTc interval with salmeterol although no statistical analysis of the difference was performed. In contrast in asthmatic patients with methacholine-induced bronchoconstriction there was no significant difference between salmeterol and formoterol in causing increased heart rate and QTc interval although formoterol caused significantly greater bronchodilation and hypokalaemia (Palmqvist 1999). Whilst there is good evidence of cardiovascular and metabolic side effects with increasing doses of beta 2 -agonists, it is a little difficult to envisage serious adverse effects of this nature when using long-acting beta 2 agonists (LABAs) at manufacturer-recommended preventative doses. However, it is possible that some patients choose to use repeated doses of LABAs during exacerbations.

\section{Tolerance}

In this setting, the term tolerance refers to an impaired response to beta 2 -agonists in patients who have been using regular beta 2 agonist treatment previously (Haney 2006). Tolerance is likely to result from a combination of reduced receptor numbers secondary to receptor internalisation and reduced production and also uncoupling of receptors to downstream signalling pathways following repeated activation (Barnes 1995). This phenomenon is likely to explain the beneficial reduction in systemic side effects seen with regular use of

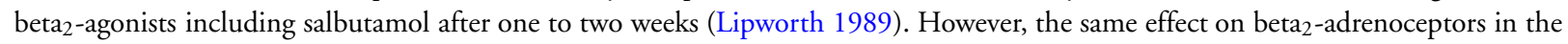
lung might be expected to produce a diminished response to the bronchodilating activity of beta 2 -agonists following regular use. In patients with stable asthma, whilst there is some evidence of tolerance to both salbutamol (Nelson 1977) and terbutaline (Weber 1982) other studies have been less conclusive (Harvey 1982; Lipworth 1989). However, evidence of tolerance to short and long-acting beta 2 agonists in both protecting against and reducing bronchoconstriction is much stronger in the setting of an acute bronchoconstrictor challenge with chemical, allergen and 'natural' stimuli (Haney 2006; Lipworth 1997). 
Studies comparing salmeterol and formoterol have shown that both cause tolerance compared to placebo but there was no significant difference between the drugs (van der Woude 2001). There also appears to be little difference in the tolerance induced by regular formoterol and regular salbutamol treatment (Hancox 1999; Jones 2001). To the authors' knowledge no studies have looked specifically at the degree of tolerance caused by isoprenaline and fenoterol in the setting of acute bronchoconstriction. Tolerance to bronchodilation has been shown clearly to occur with addition of inhaled corticosteroids to salmeterol and formoterol (Lee 2003) and terbutaline (Yates 1996). There is conflicting evidence as to whether high-dose steroids can reverse tolerance in the acute setting (Jones 2001; Lipworth 2000).

At first glance the toxicity and tolerance hypotheses might appear incompatible as systemic and cardiovascular tolerance ought to protect against toxicity in the acute setting and there is good evidence that such tolerance occurs in stable asthmatic patients (Lipworth 1989). However, whilst this study showed that changes in heart rate and potassium levels were blunted by previous beta 2 -agonist use, they were not abolished; furthermore, at the doses studied these side effects appear to follow an exponential pattern (Lipworth 1989). In contrast, in the presence of bronchoconstrictor stimuli the bronchodilator response to beta 2 -agonists follows a flatter curve (Hancox 1999; Wong 1990) and as previously discussed this curve is shifted downwards by previous beta 2 -agonist exposure (Hancox 1999). Thus, it is theoretically possible that in the setting of an acute asthmatic attack and strong bronchoconstricting stimuli, bronchodilator tolerance could lead to repetitive beta2-agonist use and ultimately more systemic side effects than would otherwise have occurred. Of course, other sequelae of inadequate bronchodilation including airway obstruction will be detrimental in this setting.

Whilst the tolerance hypothesis is often cited as contributing towards the asthma mortality epidemics it is difficult to argue that reduced efficacy of a drug can cause increased mortality relative to a time when that drug was not used at all. However, tolerance to the bronchodilating effect of endogenous circulating adrenaline is theoretically possible and there is also evidence of rebound bronchoconstriction when stopping fenoterol (Sears 1990), which may be detrimental. Furthermore, it appears that regular salbutamol treatment can actually increase airway responsiveness to allergen (Cockcroft 1993) a potentially important effect that could form a variant of the toxicity hypothesis. Differences between beta 2 -agonists in this regard are unclear, but the combination of rebound hyper responsiveness and tolerance of the bronchodilator effect with regular beta 2 -agonist exposure has been recently advocated as a possible mechanism to explain the association between beta 2 -agonists and asthma mortality (Hancox 2006a).

\section{Other explanations}

\section{Confounding by severity}

Historically, this hypothesis has been used extensively to try to explain the association between mortality and the use of fenoterol during the 1970s New Zealand epidemic (see Pearce 2007) and is still quoted today. The hypothesis essentially relies on the supposition that

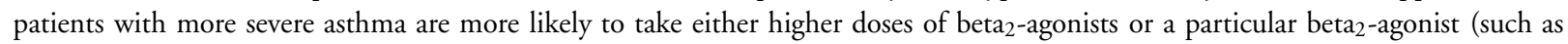
fenoterol) thereby explaining the association. This hypothesis was carefully ruled out in the three case-control studies by comparing the association between fenoterol and mortality in patients with varying severity of disease (Crane 1989; Grainger 1991; Pearce 1990). Furthermore, the hypothesis cannot explain the overall increase in mortality in the 1960s and 1970s nor can it explain any significant increase in mortality (whether taking inhaled steroids or not) from randomised controlled trial data.

\section{The delay hypothesis}

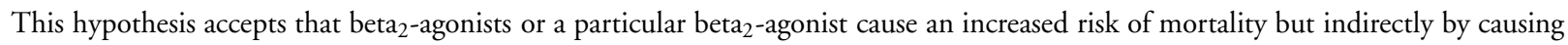
patients to delay before getting medical help and further treatments including high-dose steroids and oxygen. There is evidence that both salmeterol and formoterol can reduce awareness of worsening underlying inflammation (Bijl-Hofland 2001; McIvor 1998). It is difficult to rule out the delay hypothesis in either explaining or contributing towards both the asthma mortality epidemics and an association with regular use of LABAs. There is evidence that beta 2 -agonists with higher intrinsic efficacy are more effective at relieving bronchoconstriction in the acute setting (Hanania 2007) and could paradoxically cause patients to delay seeking medical help for longer. For the delay hypothesis to explain the increase in mortality during the 1960s and 1970s one has to imply that hospital treatment of asthma when mortality rates were low during the earlier years of the $20^{\text {th }}$ century was effective. It is difficult to say exactly how effective such treatment is likely to have been. 


\section{Reduced corticosteroid treatment}

A slight but significant variation of the delay hypothesis suggests that patients who have separate beta 2 -agonists and corticosteroid inhalers may choose to take less corticosteroid because of better symptom control from the inhaled beta 2 -agonists and it is reduced corticosteroid treatment that contributes to a rise in mortality. It is rather difficult to see how this hypothesis explains the epidemics of asthma deaths in the 1960s and 1970s relative to the 1920s and 30s (Figure 5), given that corticosteroids were not used for the treatment of asthma in the earlier decades. If this hypothesis were to explain increased mortality from more recent randomised controlled trial data one would not expect to see an increase in mortality in those taking LABAs alone.

Figure 5. Changes in asthma mortality (5 to 34 age group) in three countries in relation to the introduction of isoprenaline forte in the UK and New Zealand and of fenoterol in New Zealand. (From Blauw 1995. With permission from the Lancet).

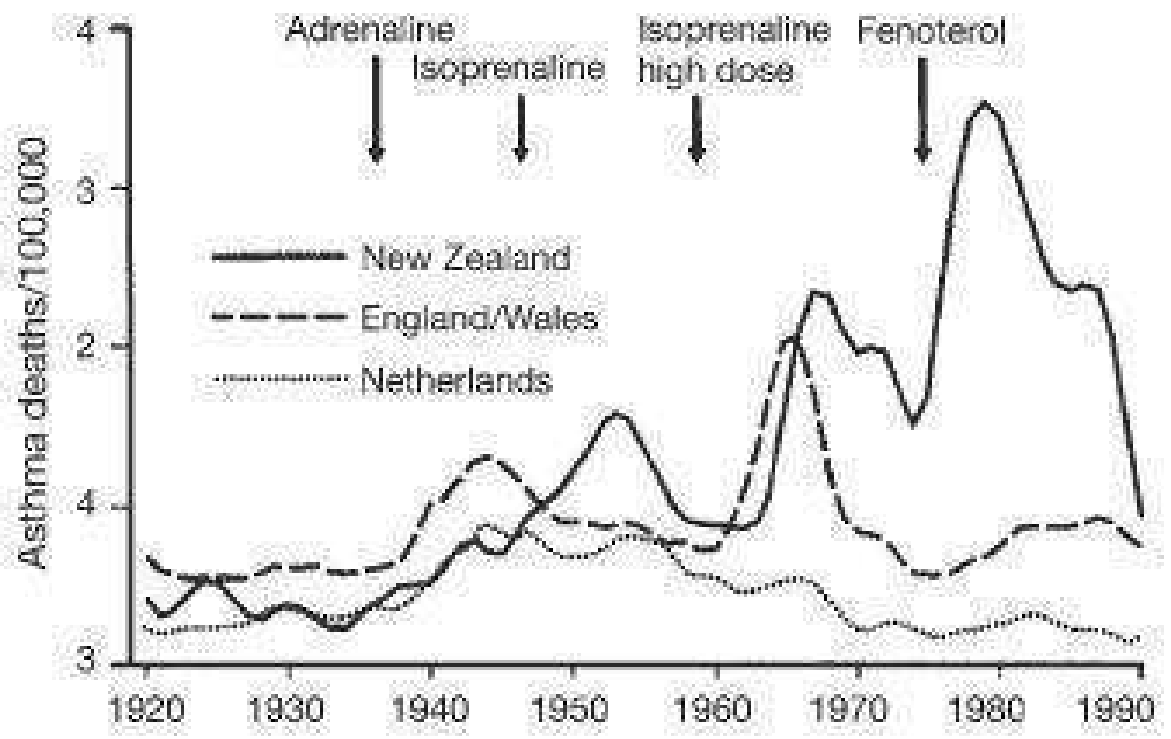

\section{Appendix 3. Definition of serious adverse event (SAE)}

A SAE is any adverse event occurring at any dose that results in any of the following outcomes:

1. Death

2. A life-threatening adverse event

3. Inpatient hospitalisation or prolongation of existing hospitalisation

4. A disability/incapacity

5. A congenital anomaly in the offspring of a subject who received medication

6. Important medical events that may not result in death, be life-threatening or require hospitalisation may be considered a serious adverse event when, based upon appropriate medical judgement, they may jeopardise the patient or subject and may require medical or surgical intervention to prevent one of the outcomes listed in this definition. Examples of such medical events include allergic bronchospasm requiring intensive treatment in an emergency room or at home, blood dyscrasias or convulsions that do not result in inpatient hospitalisation, or the development of medication dependency or medication abuse. 


\section{Clarifications}

"Occurring at any dose" does not imply that the subject is receiving study medication.

Life-threatening means that the subject was, in the view of the investigator, at immediate risk of death from the event as it occurred. This definition does not include an event that, had it occurred in a more severe form, might have caused death.

Hospitalisation for elective treatment of a pre-existing condition that did not worsen during the study is not considered an AE.

Complications that occur during hospitalisation are AEs. If a complication prolongs hospitalisation, the event is a SAE.

"Inpatient" hospitalisation means the subject has been formally admitted to a hospital for medical reasons. This may or may not be overnight. It does not include presentation at a casualty or emergency room.

With regard to criterion number 6 above, medical and scientific judgement should be used in deciding whether prompt reporting is appropriate in this situation.

\section{Events or outcomes not qualifying as SAEs}

The events or outcomes identified as asthma exacerbations will be recorded in the asthma exacerbations page of the case report form (CRF) page if they occur. However, these individual events or outcomes, as well as any sign, symptom, diagnosis, illness and/or clinical laboratory abnormality that can be linked to any of these events or outcomes, are not reported to GW as SAEs even though such event or outcome may meet the definition of SAE, unless the following conditions apply:

- the investigator determines that the event or outcome qualifies as a SAE under criterion number 6 of the SAE definition (see Section 7.2., Definition of a SAE), or the event or outcome is in the investigator's opinion of greater intensity, frequency or duration than expected for the individual subject, or death occurring for any reason during a study, including death due to a disease-related event.

\section{Appendix 4. Sources and search methods for the Cochrane Airways Group Specialised Register (CAGR)}

\section{Electronic searches: core databases}

\begin{tabular}{ll}
\hline Database & Frequency of search \\
\hline MEDLINE (Ovid) & Weekly \\
\hline EMBASE (Ovid) & Weekly \\
\hline CENTRAL (The Cochrane Library) & Quarterly \\
\hline PSYCINFO (Ovid) & Monthly \\
\hline CINAHL (EBSCO) & Monthly \\
\hline AMED (EBSCO) & Monthly \\
\hline
\end{tabular}

\section{Handsearches: core respiratory conference abstracts}




\begin{tabular}{l|l}
\hline Conference & Years searched \\
\hline American Academy of Allergy, Asthma and Immunology (AAAAI) & 2001 onwards \\
\hline American Thoracic Society (ATS) & 2001 onwards \\
\hline Asia Pacific Society of Respirology (APSR) & 2004 onwards \\
\hline British Thoracic Society Winter Meeting (BTS) & 2000 onwards \\
\hline Chest Meeting & 2003 onwards \\
\hline European Respiratory Society (ERS) & $1992,1994,2000$ onwards \\
\hline International Primary Care Respiratory Group Congress (IPCRG) & 2002 onwards \\
\hline Thoracic Society of Australia and New Zealand (TSANZ) & 1999 onwards \\
\hline
\end{tabular}

\section{MEDLINE search strategy used to identify trials for the CAGR}

\section{Asthma search}

1. exp Asthma/

2. asthma\$.mp.

3. (antiasthma $\$$ or anti-asthma $\$$ ).mp.

4. Respiratory Sounds/

5. wheez\$.mp.

6. Bronchial Spasm/

7. bronchospas $\$$.mp.

8. (bronch\$ adj3 spasm\$).mp.

9. bronchoconstrict $\$ . m p$.

10. exp Bronchoconstriction/

11. (bronch $\$$ adj3 constrict $\$$ ).mp.

12. Bronchial Hyperreactivity/

13. Respiratory Hypersensitivity/

14. ((bronchial\$ or respiratory or airway\$ or lung\$) adj3 (hypersensitiv\$ or hyperreactiv\$ or allerg\$ or insufficiency)).mp.

15. ((dust or mite\$) adj3 (allerg\$ or hypersensitiv\$)).mp.

16. or/1-15

\section{Filter to identify RCTs}

1. exp "clinical trial [publication type]"/

2. (randomised or randomised).ab,ti.

3. placebo.ab,ti.

4. dt.fs.

5. randomly.ab,ti.

6. trial.ab,ti. 
7. groups.ab,ti.

8. or/ $1-7$

9. Animals/

10. Humans/

11. 9 not (9 and 10)

12. 8 not 11

The MEDLINE strategy and RCT filter are adapted to identify trials in other electronic databases.

\section{WHAT'S NEW}

Last assessed as up-to-date: 5 January 2012.

\begin{tabular}{|c|c|c|}
\hline Date & Event & Description \\
\hline 5 January 2012 & New citation required but conclusions have not changed & No new studies found. \\
\hline 5 January 2012 & New search has been performed & $\begin{array}{l}\text { New search in January } 2012 \text { but no new studies included } \\
\text { Minor edits made and plain language summary revised }\end{array}$ \\
\hline
\end{tabular}

\section{H I S T O R Y}

Protocol first published: Issue 2, 2009

Review first published: Issue 4, 2009

\section{CONTRIBUTIONSOFAUTHORS}

CJC: conception of the idea and co-writing of protocol and review.

TL: co-writing of the protocol and review.

\section{DECLARATIONS OF INTEREST}

None known.

\section{SOURCES OF SUPPORT}




\section{Internal sources}

- No sources of support supplied

\section{External sources}

- NHS R\&D, UK.

National Institute of Health Research: Programme Grant

\section{DIFFERENCES BETWEEN PROTOCOLANDREVIEW}

The 'Summary of findings' table was not mentioned in the protocol and has been constructed on the basis of the primary outcomes and asthma-related SAEs. Adults and children have been described separately in the 'Summary of findings' table.

\section{N D EX TERMS}

\section{Medical Subject Headings (MeSH)}

Adrenal Cortex Hormones [therapeutic use]; Adrenergic beta-Agonists [adverse effects]; Albuterol [adverse effects; ${ }^{*}$ analogs $\&$ derivatives]; Anti-Asthmatic Agents [*adverse effects]; Asthma [* ${ }^{*}$ rug therapy; mortality]; Chronic Disease; Ethanolamines [ ${ }^{*}$ adverse effects]; Randomized Controlled Trials as Topic

\section{MeSH check words}

Adult; Child; Humans 